\title{
Fire Ants (Solenopsis spp.) and Their Natural Enemies in Southern South America
}

\author{
Juan Briano, Luis Calcaterra, and Laura Varone \\ USDA-ARS-South American Biological Control Laboratory, Bolivar 1559, B1686EFA Hurlingham, Argentina \\ Correspondence should be addressed to Juan Briano, jabriano@speedy.com.ar
}

Received 8 August 2011; Revised 4 October 2011; Accepted 14 October 2011

Academic Editor: Jean Paul Lachaud

Copyright () 2012 Juan Briano et al. This is an open access article distributed under the Creative Commons Attribution License, which permits unrestricted use, distribution, and reproduction in any medium, provided the original work is properly cited.

\begin{abstract}
We review the fire ant research conducted by the ARS-South American Biological Control Laboratory (SABCL) since 1987 to find a complex of natural enemies in southern South America and evaluate their specificity and suitability for field release as selfsustaining biological control agents. We also include those studies conducted by the ARS-Center for Medical, Agriculture, and Veterinary Entomology in the United States with the SABCL collaboration. Ecological and biological information is reported on local fire ants and their microsporidia, nematodes, viruses, phorid flies, eucharitid wasps, strepsiptera, and parasitic ants. Their biology, abundance, distribution, detrimental effect, field persistence, specificity, and phenology are discussed. We conclude that the objectives of the ARS program in South America are being achieved and that the pioneering studies have served to encourage further investigations in the United States and other countries and advanced the implementation of biological control programs to decrease imported fire ant densities and damage. Still, several promising organisms should be further investigated for eventual field release in the near future.
\end{abstract}

\section{Introduction}

The ant genus Solenopsis Westwood (Hymenoptera: Formicidae: Myrmicinae) is represented in South America by 16 native species known as "fire ants" [1]. While, in general, these ants cause occasional local problems in their homeland, two species accidentally introduced into the southern United States in the early 1900 s are considered pests with a high negative impact in rural and urban areas [2]. These pest species are the red imported fire ant, Solenopsis invicta Buren, and the black imported fire ant, $S$. richteri Forel, both included in a revision of the S. saevissima complex [3].

During the last decade, $S$. invicta has been considered one of the 100 worst invasive exotic species [4]; this fire ant became a more global problem when it invaded ecosystems in the Caribbean Islands [5], Australia [6], New Zealand [7], Hong Kong, Taiwan [8], and mainland China [9]. Its eradication has been accomplished only in New Zealand [10].

In the United States, the imported fire ants cause many problems in the southeast and in some patches in California. They are a major public health concern because of their aggressive stinging behavior [11]. Although, for most individuals, this is just an irritating nuisance, for several hundred thousand people in the United States, sensitive to fire ants or highly allergic, the sting might cause severe reactions and eventually death [12]. Fire ants also injure domestic animals, livestock, affect wildlife [13, 14], native ants, and other arthropods $[15,16]$. Structures, electrical devices, and agricultural crops can also be damaged $[17,18]$.

In disturbed North American environments, imported fire ants are dominant terrestrial arthropods [19]. Solenopsis invicta has displaced Neartic species of fire ants in the United States and adversely affected the diversity of the ant assemblages $[15,16]$; however, the nature of the impact on native ant species has been controversial [20]. Some beneficial effects of fire ants such as predation on several agricultural and livestock pests have been also reported [20,21].

In the United States, chlorine insecticides were used to control fire ants in the 1950s and 1960s, but they brought negative consequences to the environment [21]. A new bait with the insecticide mirex was believed to make fire ant eradication possible. However, in 1971, its use was highly restricted because of many environmental concerns and 
mirex registration was cancelled in 1977 [11, 21]. Since the 1980s, more environmentally friendly products have been used in the United States [11] and in other invaded countries. Still, the chemical approach is expensive, only provides temporary control, is detrimental to several nontarget organisms, and is not appropriate for large and/or sensitive environments. Consequently, the need of implementing control methods with less negative environmental impacts became a priority.

The first serious interest in biological control of fire ants was shown by the United States in the late 1960s. Scientists from the University of Florida and the ARS-Insects Affecting Man and Animals Research Laboratory (IAMARL, now the Center for Medical, Agricultural, and Veterinary Entomology, CMAVE), both in Gainesville, FL, conducted the first surveys for natural enemies in Brazil, Uruguay, and Argentina and provided information on several potential candidates [22-24].

In late 1987, after three years of cooperative work with Brazilian researchers in Mato Grosso and Mato Grosso do Sul, Brazil, scientists from the IAMARL formally established the fire ant biological control program at the ARSSouth American Biological Control Laboratory (SABCL) in Hurlingham, Buenos Aires province, Argentina [25]. Since then, the main objective of the program has been to find a complex of natural enemies of fire ants in their homeland, evaluate their specificity, and determine their suitability for eventual use in the United States against the red and black imported fire ants.

In this paper, we review the fire ant research conducted by SABCL researchers in southern South America since 1987. Several studies carried on in the United States by CMAVE scientists in collaboration with SABCL researchers are also included. We cover not only the occurrence of fire ant natural enemies and aspects of their biology and ecology, but also ecological studies on other South American fire ants.

\section{Fire Ants in Southern South America}

South American fire ants occur in almost all habitats from the Amazon Basin of Brazil to $42^{\circ} \mathrm{S}$ in Río Negro province, Argentina [1,26-28], and up to more than $3,200 \mathrm{~m}$ of altitude in the Puna region in the Andes [29]. Solenopsis invicta occurs along most of the Río de la Plata basin from the vicinity of Rosario, Santa Fe province, Argentina, to Paraguay, southern Brazil and eastern Bolivia [1, 28] (Figure 1). Recent surveys revealed that mitochondrial DNA haplotypes of $S$. invicta are distributed in Argentina up to $33^{\circ} 41^{\prime} \mathrm{S}$ in Mercedes, San Luis province, and $64^{\circ} 52^{\prime} \mathrm{W}$ and $1,100 \mathrm{~m}$ of altitude in the Calilegua National Park, Jujuy province [29-31]. The occurrence of S. invicta in the Amazon basin has been controversial since it has been previously recorded in Porto Velho, Rondonia state, Brazil [28], but it was virtually absent in more recent studies [30, 31]. Solenopsis richteri is native to central Argentina, southern Uruguay, and Brazil. In Argentina, it occurs mainly in the pampas surrounding Buenos Aires and along the lower reaches of the Río de la Plata basin, up north to Rosario area. Other common fire ant species in southern South
America are S. quinquecuspis Forel, mostly cooccurring with S. richteri; S. magdonaghi Santschi, mostly cooccurring with S. invicta; S. interrupta Santschi, mostly cooccurring with S. electra Forel in northwestern Argentina and Bolivia; $S$. weyrauchi Trager, mostly occurring presumably alone above 2,000 m of altitude throughout the Andes from Perú to Argentina $[1,30]$.

Hundreds of studies on introduced populations of the red and black imported fire ants have been published since the 1970s, several of which have attributed their invasion success to the adaptation to disturbed habitats, the escape from natural enemies, or the competitive superiority [20, 32]. Despite their widespread impact in invaded habitats, little was known about these species in their homeland. The first studies in their native range focused on the occurrence and detrimental effects of natural enemies such as pathogens, social parasites, and parasitoids [20, 24, 33-36].

Several ecological studies on ant assemblages were conducted during the last decade in Argentina and Brazil [30, 37-42]. These studies were oriented (1) to know the position of S. invicta in the hierarchy of dominance of the ant assemblages, cooccurring not only with many competitor ants but also with their natural enemies, and (2) to investigate if its success in the introduced range is the consequence of a lowcompetitive environment more than the relative absence of their natural enemies [38-40]. These works revealed that, in several ant assemblages in Argentina and Brazil, overall, $S$. invicta occupied the top in the ecological dominance hierarchy, being the ant most frequently captured (64-82\% of the samples) and numerically abundant (23-27\% of total individuals captured) without showing the highest biomass. Most assemblages included at least $8-10$ ant species that were also very common [38-42].

The ecological studies also showed that $S$. invicta was frequently a slow discoverer but almost always a good dominator of the food resources, allowing other cooccurring species of ants to be abundant [38-40]. This would indicate that its success was not necessarily based on the break of the discovery-dominance tradeoff, as it has been found in other invasive species, such as the Argentine ant, Linepithema humile (Mayr). Despite not being a good discoverer, $S$. invicta won, on average, $75 \%$ of the interactions in five ant assemblages in northern Argentina [38, 39] and Brazil [40]. In Argentina, its main competitor was Pheidole obscurithorax Naves (also exotic in the United States). Its ecological dominance was based on (1) the large numbers of individuals, (2) the well-developed recruitment system, (3) the aggressive behavior, and (4) the uninterrupted-foraging activity [30, 38-40].

The situation in southern South America strongly contrasts with that observed in North America, where S. invicta is the unique dominant ant representing most ant biomass $[17,20,32]$. At least in Argentina, the strong competitive environment and the indirect effect of natural enemies were suggested to be the most important factors limiting the success of $S$. invicta. Competitors and natural enemies would likely be locally adapted to the genetically divergent $S$. invicta populations inhabiting different parts of South America. An assessment of its genetic variation using 2,144 colonies from 


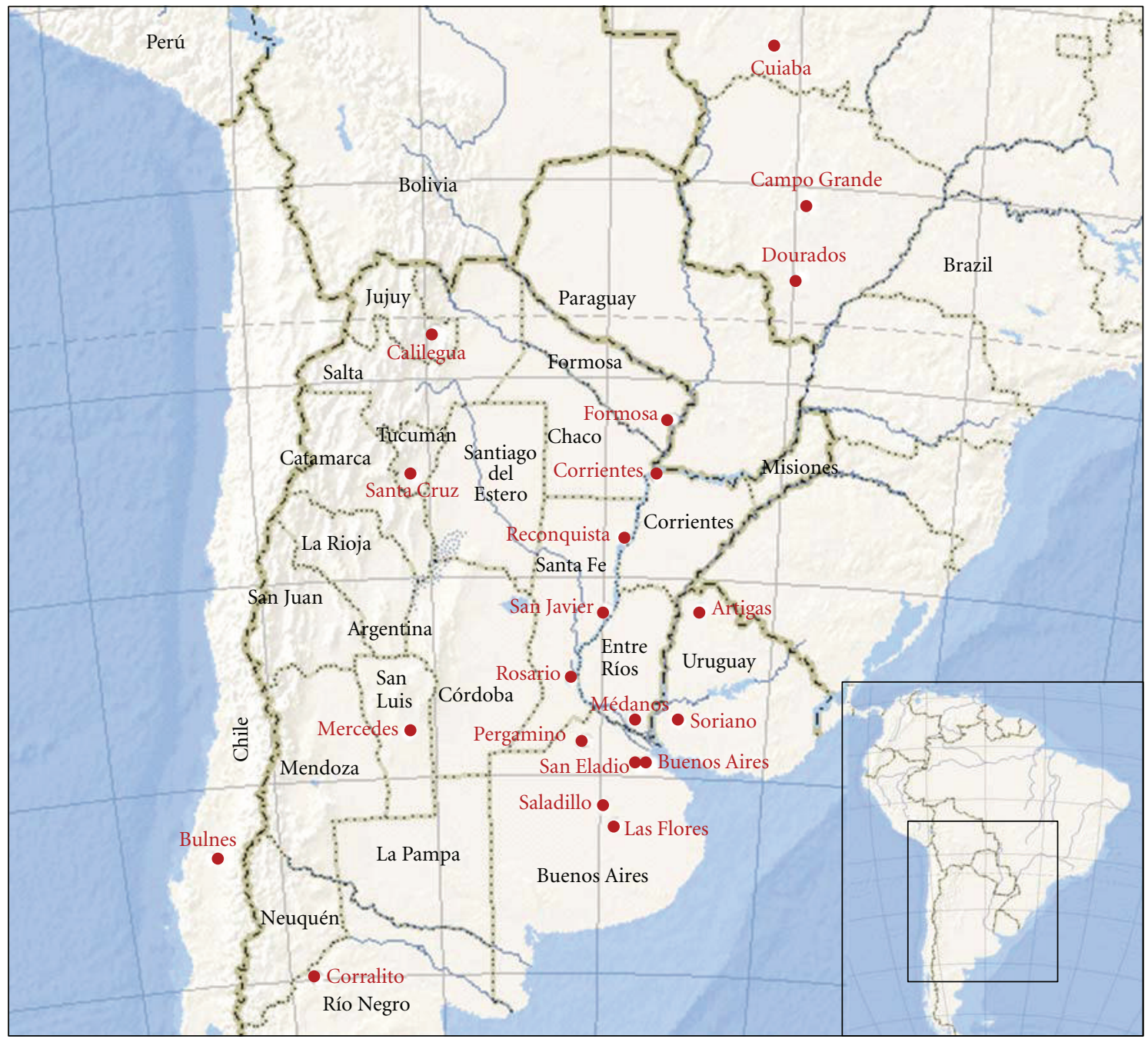

FIgURE 1: Red dots showing localities in Argentina, Brazil, Uruguay, and Chile mentioned in the paper.

75 sites worldwide revealed that around $97 \%$ of all known mt DNA haplotypes of $S$. invicta only occur in the native range [31]. The dominant haplotypes in the United States and other newly invaded areas occur only at low frequencies $(<5 \%)$ in eight populations in Formosa province (Figure 1) in northeastern Argentina [31], indicating that this area is more likely to be the source of S. invicta in the United States [43].

\section{Natural Enemies}

3.1. Pathogens. Preliminary explorations for fire ant diseases in Argentina were conducted by researchers from IAMARL and SABCL in 1987 in the provinces of Buenos Aires, Entre Ríos, and Santa Fe [25]. The vial sampling of 425 fire ant colonies in 47 sites and the subsequent microscopic examination revealed the presence of the following pathogens: (1) Kneallhazia (=Thelohania) solenopsae Knell, Allen, and Hazard (Microsporidia: Thelohaniidae) at $41 \%$ of the sites and $11 \%$ of the colonies; (2) Vairimorpha invicta Jouvenaz and Ellis (Microsporidia: Burenellidae) at $11 \%$ of the sites and 2\% of the colonies; (3) Myrmecomyces annellisae Jouvenaz and Kimbrough (Deuteromycotina: Hyphomycetes) at $15 \%$ of the sites and $2 \%$ of the colonies; (4) Mattesia sp. (Neogregarinida) at $7 \%$ of the sites and $1 \%$ of the colonies; (5) a mermithid nematode at $7 \%$ of the sites and $0.5 \%$ of the colonies. This preliminary overall occurrence of K. solenopsae and $V$. invictae in $13 \%$ of the colonies of S. richteri and $S$. quinquecuspis almost doubled the prevalence (7.6\%) of the same infections on $S$. invicta in the area previously surveyed of southwestern Brazil [25].

3.1.1. Microsporidia. Kneallhazia solenopsae and V. invictae are obligate intracellular pathogens first discovered infecting mainly the fat body of fire ants collected in the area of Cuiabá, Mato Grosso, Brazil [22, 44-46] (Figure 1). Both microsporidia show immature vegetative stages and reproductive stages represented by spore dimorphism with basically eight meiospores (octospores) bound by a membrane and nonbounded, or free, binucleate spores. More recent ultrastructural studies on $K$. solenopsae showed the presence of several other spore morphotypes [47-50]. 
Field Surveys. Subsequent surveys conducted in 1988 were mostly concentrated on microsporidia of S. richteri and $S$. quinquecuspis in Buenos Aires province to select a field site for long-term ecological studies [51, 52]. The microscopic (phase-contrast) examination of 1,836 samples of fire ant colonies from 185 roadside sites revealed the presence of K. solenopsae (Figure 2) at $25 \%$ of the sites and $8 \%$ of the colonies and $V$. invicta (Figure 3 ) at $5 \%$ of the sites and $1 \%$ of the colonies. In some sites, $K$. solenopsae showed epizootic levels infecting $40-80 \%$ and $V$. invictae infecting $60 \%$ of the colonies.

This prevalence was the highest reported for South America. Simultaneous, or dual, infections of K. solenopsae and $V$. invictae in the same colony were not detected. The area of Saladillo, $180 \mathrm{~km} \mathrm{SW}$ of Buenos Aires (Figure 1), was selected for long-term studies on S. richteri populations infected with $K$. solenopsae (see Detrimental Effect). At this stage, the fungus $M$. annellisae was found in $6 \%$ of the sites and $1 \%$ of the colonies; Mattesia sp. and the mermithid nematode were not found.

From 1991 to 1999, explorations were extended to northern Argentina in the search for $K$. solenopsae and, mainly, $V$. invictae infecting S. invicta [53]. The sampling of 2,528 fire ant colonies in 154 sites revealed the presence of $K$. solenopsae at almost $43 \%$ of the sites and in $12 \%$ of the colonies and $V$. invictae at $13 \%$ of the sites and in $2.3 \%$ of the colonies. Again, some sites in northcentral Santa Fe province showed more epizootic levels of $V$. invictae with up to $50 \%$ of the colonies infected; some of these sites were selected for long-term studies on $S$. invicta populations infected with $V$. invictae (see Detrimental Effect).

Both microsporidia were sympatric in 12 sites, in three of which 7 dual infected colonies (S. richteri and S. macdonaghi in Entre Ríos and S. invicta in Santa Fe) were found. This very low overall prevalence of dual infections $(7 / 2,528=$ $0.0028=0.3 \%$ ) was identical to the combined probability of finding at random $K$. solenopsae (12\%) and V. invictae $(2.3 \%)$ simultaneously in the same colony $(0.12 \times 0.023=0.0028=$ $0.3 \%)$.

In 1993, a brief and opportunistic sampling of $61 \mathrm{~S}$. invicta colonies at 18 sites in the area of Cuiabá (type locality for $K$. solenopsae and $V$. invictae) revealed the presence of $21 \%$ of the colonies infected with $K$. solenopsae and $6.6 \%$ with $V$. invictae (Briano and Patterson, unpublished data).

At least in Argentina and Paraguay, K. solenopsae and $V$. invictae showed the ability to infect both monogyne and polygyne colonies of $S$. invicta and S. richteri. In a sampling of $20 \mathrm{~S}$. invicta colonies infected with $\mathrm{K}$. solenopsae, $45 \%$ were polygyne and $55 \%$ were monogyne colonies; from 15 S. invicta colonies infected with $V$. invictae, $46 \%$ were polygyne and 54\% were monogyne colonies [54]. Similarly, it was found that in a population of 41 colonies of $S$. richteri infected with $K$. solenopsae, $42 \%$ of the colonies were polygyne and 58\% were monogyne [55].

It is important to remark that, during the course of the investigations in Argentina on $K$. solenopsae, this microsporidium was suddenly discovered in the United States [56] and subsequently found in most southern states. This fact redirected some of the studies on this candidate,

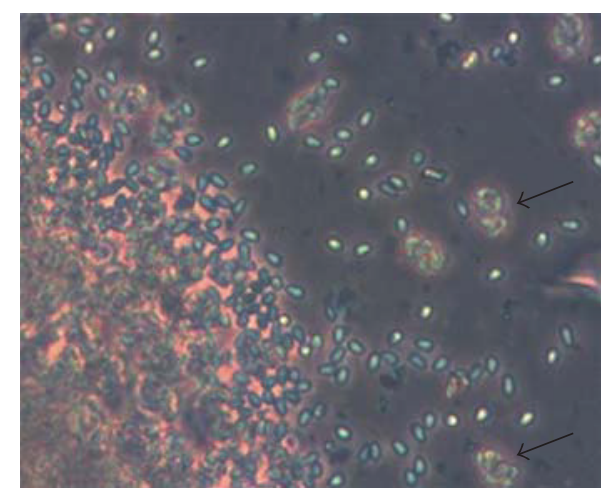

Figure 2: Phase contrast view (400x) of meiospores of Kneallhazia solenopsae in workers of Solenopsis richteri. Because of the grinding process, the octect membrane usually brakes and most spores are released in the aqueous extract. A few intact octects (arrows) are shown with meiospores inside.

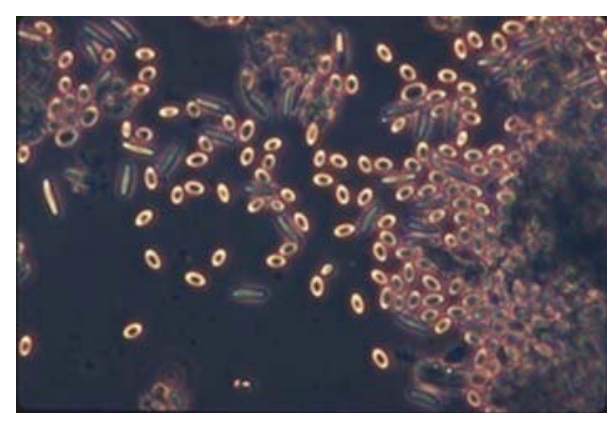

FIgure 3: Phase contrast view (400x) of ovoid meiospores (octospores) and bacilliform binucleate free spores of Vairimorpha invictae in workers of Solenopsis invicta. Again, most octects with meiospores brake during the grinding process.

since its presence in the US represented a change in the biological control approach for S. invicta.

New surveys for $V$. invictae and $K$. solenopsae were conducted from 2001 to 2005 in several central and Northern provinces (temperate and subtropical) of Argentina and in limited areas of Paraguay, Brazil, Chile, and Bolivia [57], including large western regions previously unexplored. A total of 2,064 colonies were sampled in 262 sites in roadsides, pastures, and recreational areas. Vairimorpha invictae was found at $12 \%$ of the sites and $10 \%$ of the colonies in Argentina, Brazil, Paraguay, and Bolivia. The provinces of Santa Fe and Entre Ríos showed the highest prevalence of infected colonies (20 and 7\%, resp.); in certain S. invicta sites in Santa Fe (San Javier and vicinities; Figure 1), the prevalence was 50-54\%, and, in S. richteri sites in Entre Ríos (Médanos), the prevalence was 60\%. The prevalence of $V$. invictae in Paraguay and Bolivia was very low. Kneallhazia solenopsae showed a wider distribution occurring at $25 \%$ of the sites and $13 \%$ of the colonies and was reported for the first time in western and northwestern Argentina and Bolivia, at altitudes of almost 2,300 $\mathrm{m}$ and colder weather. It was also first reported infecting S. interrupta [57]. The province of Buenos Aires showed the highest prevalence with $68 \%$ of 
infected sites and $34 \%$ of infected colonies. This time, both microsporidia cooccurred in 11 sites, 10 of which showed 46 dual infected colonies in several provinces. This prevalence of dual infections $(46 / 2,064=0.0223=2.2 \%)$ was higher than the combined probability of finding K. solenopsae (13\%) and V. invictae $(10 \%)$ simultaneously in the same colony $(0.13 \times$ $0.10=0.013=1.3 \%)$ and was the consequence of repeated and planned samplings in sites with high prevalence of dual infections. The highest prevalence of dual infections was found in Santa Fe with 3.9\% of S. invicta infected colonies and in Entre Ríos with $2.7 \%$ of S. richteri infected colonies.

Intracolonial Prevalence. The intracolonial prevalence of $K$. solenopsae in fire ant colonies (mainly $S$. richteri) was very high. Vegetative stages (Figure 4) infected 28\% (range 20$45 \%$ ) of the immature fire ants including eggs and only $1.2 \%$ of the queens, while mature stages (spores; Figure 2) infected $42.3 \%$ (range $34-95 \%$ ) of the workers, sexual adults, and queens and $0.8 \%$ of the pupae [58]. The presence of infected eggs revealed transovarial (vertical) transmission of K. solenopsae. The mean number of meiospores per worker ranged from $9 \times 10^{5}$ to $6.7 \times 10^{6}$. Free spores were extremely rare.

The intracolonial prevalence of $V$. invictae in fire ant colonies (mainly $S$. invicta) was also very high in most ant castes and stages [53]. Vegetative stages infected 30\% (range $17-52 \%$ ) of the fire ant larvae and $4.8 \%$ of the queens. Low prevalence of vegetative stages was also detected in a few eggs, providing evidence for transovarial transmission. However, the importance of the vertical transmission in the life cycle of $V$. invictae remained uncertain. Meiospores and binucleate spores of $V$. invictae (Figure 3 ) were found in all fire ant castes except eggs. Meiospores infected 33\% (range 5-56\%) of mature ants, and binucleate spores infected 39\% (range 9.5-63\%) of immature and mature ants. The occurrence of $V$. invictae was much more common in sexual males than in females. The mean number of meiospores per worker ranged from $1.2 \times 10^{4}$ to $6.4 \times 10^{4}$. Free binucleate spores of $V$. invicta in S. invicta were much more common than those of $K$. solenopsae in S. richteri, ranging from $3.2 \times 10^{3}$ to $1.6 \times$ $10^{4}$.

Dual infections showed lower intracolonial prevalence. In S. invicta, it ranged from 4.5 to $22 \%$ of the individual pupae, workers, and sexual females. In S. richteri and $S$. macdonaghi, dual infections were found only in $2.7 \%$ of the workers [53]. Dual infections were suggested to represent an important mortality factor for fire and colonies, but it was never confirmed with appropriate laboratory tests.

Detrimental Effect. The long-term field effect of K. solenopsae on S. richteri was studied in 6 plots established in natural pastures in the area of Saladillo, Buenos Aires province, and monitored 4-10 times per year from October 1988 to January 1993 for the density of colonies and the infection rates $[51,59,60]$. The study included the identification, sampling, and mapping of 1,348 active colonies. Although the fire ant densities showed cyclic variations unrelated to seasons, the overall density decreased from 162 to 28 colonies per hectare by the end of the study. The proportion of infected

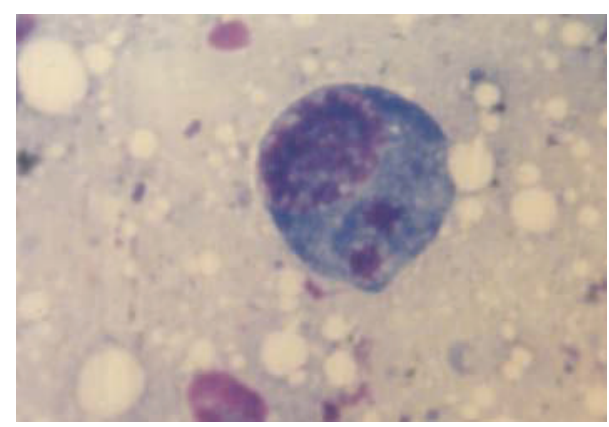

FIGURE 4: Cell of a Solenopsis richteri larva infected with a binucleate vegetative stage of Kneallhazia solenopsae. Giemsa's stain, 1000x.

colonies was very variable during the study and was positively related to rainfall. A weak negative association was found between the density of colonies and the rate of infection. The reduction of fire ant densities was attributed to the presence of $K$. solenopsae, although the loss of control plots because of natural dissemination of the infection obscured conclusive results.

During 9 months in 1992, the mound volumes of $84 \mathrm{~K}$. solenopsae-infected colonies were compared with 88 healthy colonies from two different areas [55]. The presence of polygyny, number of queens per colony, and presence and abundance of brood and myrmecophiles were also compared between infected and healthy colonies. There was a strong negative association between mound size and infection with $K$. solenopsae. The mounds of infected colonies (mean \pm SD: $4.9 \pm 1.0$ liters) were substantially smaller than those of healthy ones of the two different areas $(14.7 \pm 1.8$ and $18.7 \pm 1.7$ liters $)$. No difference was found in the volumes of infected monogyne and polygyne colonies. The presence of multiple queens was common in both infected and healthy colonies, and the number of queens per colony did not differ significantly. The infection of $K$. solenopsae had no effect on worker brood presence, but there was less sexual brood in infected colonies. All the myrmecophiles found, Neoblissus parasigaster Bergroth (Hemiptera: Lygaeidae), Martinezia sp. (Myrmecaphodius) (Coleoptera: Scarabeidae), Myrmecosaurus sp. (Coleoptera: Staphylinidae), and the social parasite Solenopsis daguerrei (Santschi) were as common in infected as well as in healthy colonies, but $N$. parasigaster was more numerous in infected colonies. Within the Saladillo plots, no effect of $K$. solenopsae was reported on the fire ant colony movement [61].

The lethal effect of $K$. solenopsae was suggested for polygyne colonies of $S$. richteri originally collected in the field and later fragmented in the laboratory to one queen and 100 workers. The fragmented colonies were reared in small plastic containers for their residual longevity [62]. After 3 months of rearing, the mortality was $92 \%$ for infected colonies $(n=14)$ and only $49 \%$ for healthy colonies $(n=$ 22).

In 1995 and 1996, the survival of 224 starved individual minor and major workers and 13 sexual females selected at random from infected and healthy colonies of $S$. richteri was compared [62]. At $27^{\circ} \mathrm{C}$, the mortality rate of infected 
workers was higher than that of healthy workers. Although the final mortality rate of infected and healthy sexual females was similar, the mortality rates occurred much sooner for infected sexuals. No differences were detected in the live weight of infected and healthy workers (minor or major). In a similar survival test with workers of $S$. invicta infected with $V$. invictae, mortality rates of infected workers were much higher than those of healthy ones [53].

The long-term field effect of $K$. solenopsae and $V$. invictae on $S$. invicta was studied in 8 roadside plots established in Santa Fe province and monitored 3-5 times per year from May 2000 to March 2004 for the density of colonies, the USDA population index (PI), and the infection rates [63]. As in the study of $S$. richteri, control plots were lost since they suffered the natural spread of the infections, making difficult the analysis of the results. Although the mean PI per plot showed abrupt reductions followed by reinfestations, important reductions of 53-100\% were observed at the end of the test in 7 of the 8 plots, resulting in an overall PI reduction of $69 \%$. From the total 394 colonies sampled, $82.5 \%$ were healthy and $17.5 \%$ were infected. The percentage of infection with both microsporidia also showed fluctuations and an overall reduction from 26 to $5 \%$ of infection rates. Only 3 colonies were found with dual infections in 2 plots. The proportion of infected and healthy colonies in the PI categories was significantly different for medium and large colonies with worker brood. More than 97\% of the large colonies were healthy, suggesting that infected colonies did not produce large colonies.

Field Persistence. Several observational studies on field persistence were conducted to check the occurrence of the microsporidia over time. These repeated samplings were important to recognize field sites with high prevalence of infections to be used as source sites for eventual shipping of infected colonies to the US. One S. quinquecuspis site in the area of Pergamino, $240 \mathrm{~km} \mathrm{~N}$ of Buenos Aires (Figure 1), infected with K. solenopsae was monitored every 1-2 months from October 1988 to July 1990 (Briano, unpublished data). The mean number of fire ant colonies sampled per monitoring date was 23 (range: 12-36), and K. solenopsae was always found infecting the colonies with ranges of $17-64 \%$.

Another site in Saladillo with S. richteri infected with $K$. solenopsae was monitored 9 times from Oct 1992 to Jun 1998 (Briano, unpublished data). The mean number of fire ant colonies sampled per monitoring date was 14.2 (range: 6$50)$. In seven $(78 \%)$ of the monitoring dates, K. solenopsae was found infecting from 22 to $67 \%$ of the fire ant colonies examined. In the other two sampling dates, no infected colonies were found.

Two S. richteri sites in Entre Ríos and one S. invicta site in Santa Fe infected with $K$. solenopsae and $V$. invictae were sampled 5-10 times from July 2001 to March 2005 [57]. On average, 18 colonies (range 7-70) were sampled per monitoring date and a high prevalence of both infections was detected, reaching epizootic levels in most occasions. The total prevalence of both microsporidia ranged from 46 to $78 \%$ of the colonies; in two occasions, $100 \%$ of the colonies were infected. Each microsporidium exhibited a characteristic enzootic/epizootic wave; V. invictae occurred more sporadically, with sudden fluctuations in prevalence, while $K$. solenopsae showed a more sustained prevalence with fewer fluctuations. High peaks in prevalence of K. solenopsae coincided with low peaks of prevalence of $V$. invictae and vice versa. The mutual interference of both microsporidia was never confirmed with laboratory tests; but it was suggested that the successive high levels of both infections, one at a time, might represent a more constant pressure against fire ant host populations. However, this assumption was never checked with appropriate filed tests.

Transmission. Many tests for the artificial horizontal transmission of $K$. solenopsae to individuals or colonies of $S$. invicta and S. richteri were conducted in the laboratory from 1992 to 2000 (Briano, unpublished data). Several approaches were used, such as (1) inoculation of healthy laboratory colonies with spore suspensions obtained from infected workers; (2) transference of infected fire ant larvae to healthy receptor colonies; (3) transference of infected fire ant adult workers to healthy receptor colonies; (4) transference of the myrmecophile $N$. parasigaster to healthy receptor colonies; (5) inoculation of $N$. parasigaster with spore suspensions obtained as above; (6) mixing of queenless infected colonies with healthy polygyne colonies; (7) inoculation of healthy field colonies with spore suspensions using various methods. After several days or weeks (depending on the approach used), the microscopic examination of the inoculated individuals, colonies, or myrmecophiles did not reveal infections.

However, horizontal transmission of $K$. solenopsae was achieved by scientists at CMAVE by transferring S. invicta infected brood to healthy colonies (approach number 2 above) and by mixing colonies (approach number 6 above) [64-66].

Tests were conducted to obtain artificial dual infections in $S$. richteri with $K$. solenopsae and $V$. invictae (Briano, unpublished data). Colonies infected with $V$. invictae were used as inocula with the following approaches: (1) transference of Vairimorpha-infected larvae to Kneallhaziainfected colonies; (2) transference of Vairimorpha-infected workers to Kneallhazia-infected colonies; (3) inoculation of Kneallhazia-infected colonies with Vairimorpha spore suspensions obtained from infected workers. Again, infections were not detected in the subsequent microscopic examination of the inoculated colonies.

In 2003, colonies of $S$. invicta infected with $V$. invictae were collected in Santa Fe, Argentina, and transported to quarantine at CMAVE for additional transmission tests. The following approaches were considered [67]: (1) inoculations of incipient $S$. invicta colonies reared from newly mated queens with larvae from the infected field colonies; (2) inoculations of incipient $S$. invicta colonies reared from newly mated queens with nonmelanized pupae from the infected field colonies; (3) inoculations of incipient S. invicta colonies reared from newly mated queens with larvae or melanized pupae from infected laboratory colonies; (4) inoculation of incipient $S$. invicta colonies with dead adults from the infected field colonies. The subsequent microscopic examination revealed, for the first time, positive transmission 
in $40 \%(2 / 5)$ of the inoculated colonies in approaches number 1 and number 2, 100\% (3/3) in approach number 3 , and $33 \%(2 / 6)$ in approach number 4 . Due to the limited number of colonies inoculated in each approach, the statistical analysis was not conducted. Also, the colony growths and brood volumes were significantly lower in infected than in healthy colonies.

Specificity. The field host range of K. solenopsae and V. invictae was first studied from 1993 to 2000 in eastcentral Argentina and southern Brazil by sampling terrestrial ants cooccurring with infected fire ants. Ants were sampled using 520 bait traps (glass vial with pieces of canned "Vienna sausage") in 52 preselected infected roadside sites and by hand sampling of 585 colonies (S. invicta, S. richteri, and other ants species) in 90 sites [68]. Kneallhazia solenopsae and $V$. invictae were found infecting only S. invicta, S. richteri, S. macdonaghi, and Solenopsis sp. (unidentified fire ant species), while the other ants baited/sampled in the genera Pheidole, Camponotus, Crematogaster, Linepithema, Brachymyrmex, Nylanderia (=Paratrechina), Acromyrmex, and Wasmannia were not infected. A preference of $V$. invictae for $S$. invicta was suggested [68]. The infection in S. macdonaghi was a new host record. A few meiospores of K. solenopsae also had been found in some individuals of the myrmecophile $N$. parasigaster and the parasitic ant $S$. daguerrei [51, 59], but infections in host tissue were not confirmed. More recently, empirical evidence of K. solenopsae infections on S. geminata and $S$. geminata $\times$ S. xyloni hybrid was reported from Texas and Mexico [69].

In 2004, additional studies were conducted in 5 polygyne sites in Corrientes and Santa Fe to confirm the specificity of V. invictae for Solenopsis ants [70]. All sites had high levels of $V$. invictae infections in fire ant colonies. As above, baits and hand samplings were used to collect ants and other arthropods in the immediate areas of infected fire ants. Vairimorpha invictae infections were detected only in fire ants by microscopy and PCR. The other ants tested were in the genera Ectatomma, Pachycondyla, Acromyrmex, Crematogaster, Pheidole, Wasmannia, Cephalotes (=Zacryptocerus), Dorymyrmex, Linepithema, Camponotus, Brachymyrmex, and Nylanderia. The other tested arthropods were in the orders Aranae, Odonata, Orthoptera, Homoptera, Hemiptera, Psocoptera, Coleoptera, Diptera, Lepidoptera, and Hymenoptera.

The host specificity of $V$. invictae was studied in the laboratory at CMAVE evaluating the tropical fire ant, $S$. geminata, the southern fire ant, S. xyloni, and the Argentine ant, Linepithema humile [71]. Inoculations of S. invicta brood infected with $V$. invictae into lab colonies of the three recipient ant species resulted in infections only in the control S. invicta in $60 \%$ of the colonies. However, the adoption of congeneric brood was not consistent, and, within the first two days, all the S. geminata and most of the S. xyloni colonies had moved the inoculated brood in the trash pile. In the case of the Argentine ant, the inoculated S. invicta brood was initially tended in 2 of the 6 nests. However, inocula appeared to be finally discarded from all nests. Since alien brood survival seemed to have been temporary, whether the lack

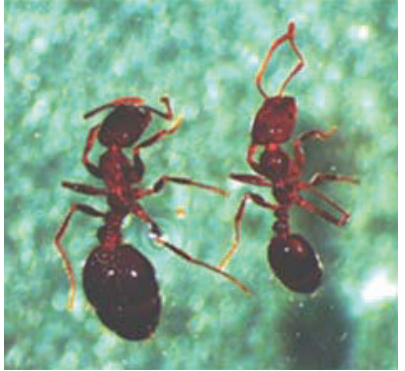

(a)

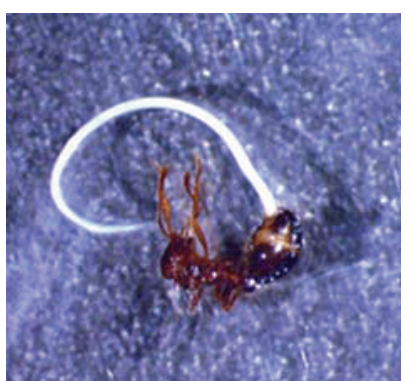

(b)
Figure 5: (a) Parasitized (left) and nonparasitized Solenopsis worker. (b) Juvenile Allomermis solenopsi emerging from worker.

of infection in the test ants was due to limited interspecific cross-fostering of brood or lack of physiological susceptibility was not determined [71].

3.1.2. Nematodes. Few records of parasitic nematodes exist for fire ants [72]. The diagnostic character for the occurrence of mermithid nematodes in ants is the enlarged gasters of the workers (Figure 5(a)). In the late 1980s, three species were reported for southern South America: (1) Tetradonema solenopsis Nickle and Jouvenaz from central-western Brazil in $2.9 \%$ of the 2,250 fire ant colonies examined; (2) a mermithid nematode from central-eastern Argentina in $0.5 \%$ of the 425 colonies examined; (3) an unidentified nematode from central-eastern Argentina, Uruguay, and southern Brazil in $4.3 \%$ of the 600 colonies sampled [73, 74].

In 2006, while researching for decapitating phorid flies in Corrientes province, Argentina, CMAVE scientist Sanford Porter redetected the presence of mermithids in S. invicta. The nematode was recently described and named as Allomermis solenopsi [72].

Surveys and Parasitism Rates. From 2006 to 2008, examination of 489 fire ant colonies in Buenos Aires and northeastern Argentina revealed infections in $17.3 \%$ of the 29 sites, where an average of $52.3 \%$ of $S$. invicta or S. richteri colonies was infected. The mean number of parasitized workers per colony was 52 (range 1-500). Also pupae were found with enlarged gasters and juvenile nematodes inside. Several positive sites were further revisited for the persistence of the infections; although the infection persisted over more than one year, the parasitism rates showed great variations (Varone, unpublished data).

Life Cycle. The life cycles of terrestrial or semiterrestrial mermithid nematodes are completely known only in a few cases [75-77]. In general, adults are free-living organisms, and developing stages are parasitic. Females usually lay eggs during periods of high moisture. Juveniles undergo one molt in the egg and emerge as a second-stage juvenile. The emerged juvenile enters the insect host through the anus, spiracles, or direct penetration through the cuticle to reach the body cavity [78]. Some species of mermithids develop little until the host reaches the adult stage and then migrate to the abdomen, mature, and kill the host on emergence [79]. 


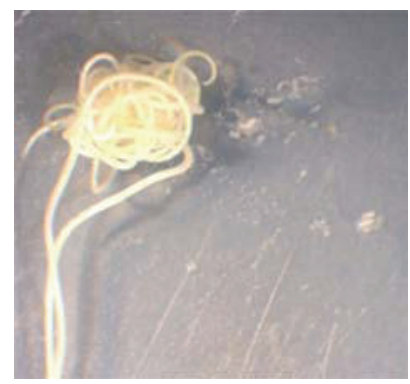

(a)

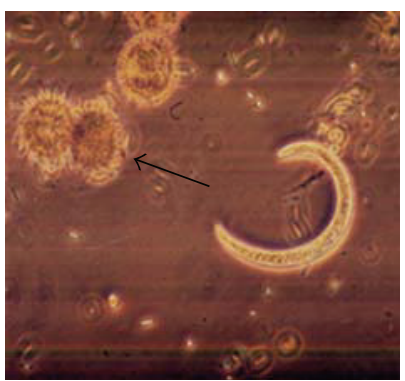

(b)
Figure 6: (a) Adults of Allomermis solenopsi forming a mating cluster and laying eggs (10x). (b) Eggs (arrow) and juvenile $A$. solenopsi (400x).

The A. solenopsi parasitism mechanism on fire ants remains unknown. However, in the laboratory, it seems that water is needed for reproduction and oviposition. It was observed that juvenile nematodes came out from dead parasitized workers only when placed in water (Porter, unpublished data). The emergence took several minutes to three days (Figure 5(b)) but failed in $65.8 \%$ of the cases. Once in the water, juvenile nematodes molted to adults and formed "mating clusters" (Figure 6(a)) with the subsequent egg laying. Juveniles were observed developing inside the eggs, and some emerged when the eggs were crushed (Figure 6(b)).

Rearing mermithid parasites of insects have been especially difficult. Since mermithids are relatively common parasites of aquatic insects, laboratory cultures have been established for a few mosquito parasites [77, 80, 81]. Creighton and Fassuliotis [82] cultured a mermithid parasite for the control of a terrestrial insect, Diabrotica balteata (Coleoptera: Chrysomelidae).

Several tests were conducted to spread the infection artificially under laboratory conditions by transferring eggs or newly emerged juveniles of $A$. solenopsi to uninfected host colonies. The juveniles were introduced to receptor colonies using hard-boiled egg, tenebrionid larvae, and crickets, or located by hand in the ant brood pile using a humid and folded wiper (Kimwipes). Parasitism was obtained only using crickets and the wiper but at very low rates.

Detrimental Effect. An important change in the behavior of infected workers was detected in the laboratory by voluntarily exposing for 10-minute 5 SABCL staff members to the fire ant sting (Varone, unpublished data). All infected workers tested $(n=10)$ lost their stinging behavior. Infected ants did not show the typical stinging position of a curved gaster, probably due to the enlarged gaster. Linear relationships were found between the sizes of the ant heads and the venom glands in 20 healthy and 20 infected workers, indicating no atrophy of the venom gland in infected workers (Varone, unpublished data).

An effect was also observed with aggression tests among workers from different colonies. Contests involving two ants, one being infected and the other not, usually only resulted in antennation, while interactions between two healthy workers mostly ended in aggression and/or fighting.

The infection with $A$. solenopsi also affected the residual survivorship of the worker ants. On average, parasitized workers $(n=872)$ survived $17.5 \pm 12.6$ days and nonparasitized ones $(n=1,078)$ survived $35.8 \pm 26.1$ days after the colony was removed from the field. Allomermis solenopsi adult survivorship as a free form in water was $10.7 \pm 9.2$ days, showing great variability among individuals with a range of 2-72 days (Varone, unpublished data).

3.1.3. Viruses. Until recently, little effort has been invested on virus infections in fire ants [36]. Virus-like particles were reported from Solenopsis ants in Brazil [83]. More recently, three positive-strand RNA viruses were discovered infecting S. invicta in the United States: SINV-1, SINV-2, and SINV3 [84-90]. These viruses were successfully transmitted to uninfected workers by feeding food. The viruses replicated within S. invicta [88] and were associated with significant mortality among workers and larvae once infected [89].

Surveys for these viruses in Argentina were conducted from 2005 to 2008 mainly on S. invicta and some S. richteri and S. quinquecuspis. Almost 400 colonies were sampled at 32 sites in the provinces of Corrientes, Chaco, Formosa Santa Fe, and Entre Ríos. In addition, 6 colonies of $S$. weyrauchi and $S$. interrupta were sampled in two sites in Bolivia along with $17 \mathrm{~S}$. macdonaghi at one site in Uruguay. In all cases, workers were preserved in ethanol 96\%. Reverse transcription polymerase chain reactions (RT-PCR) and multiplex PCR were used [91].

In Argentina, the viruses occurred in 22 (73.3\%) sites with a mean colony infection of $26 \%$. SINV-1 was present in $12(40 \%)$ sites and in $24(12.8 \%)$ colonies; SINV-2 in 8 (26.7\%) sites and $11(5.8 \%)$ colonies and SINV-3 in $2(6.7 \%)$ sites and $5(3.2 \%)$ colonies. Although SINV-1 was the most common, it frequently occurred in combination with the other two; only $29.2 \%$ of the infected colonies were exclusively infected with SINV-1, 37.5\% had double infections (SINV-1 plus SINV-2 or SINV-3), and the remaining 33.3\% were positive for all three viruses [91]. Only one S. invicta colony was exclusively infected with SINV-2. In Bolivia and Uruguay, infected colonies were not detected (Varone and Calcaterra, unpublished data).

\subsection{Parasitoids}

3.2.1. Phorid Flies. At least 30 Pseudacteon species (Diptera: Phoridae) are parasitoids of Solenopsis fire ants in the New World and 23 attack South American fire ants in the Solenopsis saevissima species group [92, 93]. Fire ant decapitating flies are parasitoids of individual workers [94, 95].

Female flies chase live worker ants (Figure 7) and, in a rapid aerial attack, insert their eggs into the thorax. After hatching, the larva migrates into the ant's head, consumes all the tissue, and ultimately decapitates the host ant. A single adult fly emerges from the oral cavity 2-6 wk after the egg was laid [96]. Once the adult fly emerges, it has only a few days to look for a mate to repeat the cycle. 


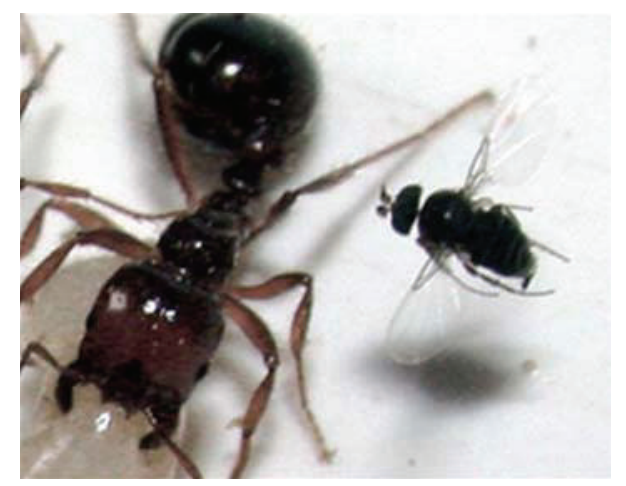

Figure 7: Pseudacteon fly chasing a Solenopsis invicta worker for oviposition (photo by S. D. Porter).

Field Surveys. Before the mid 1990s, the biology, geographical distribution, and abundance of most of these South American flies on fire ants were scarcely known. Borgmeier described most of the species [97], and extensive collections were conducted in the early 1970's [98, 99].

Large-scale surveys were conducted by SABCL and CMAVE researchers from 1995 to 2002 documenting the occurrence of $P$. tricuspis Borgmeier, P. curvatus Borgmeier, P. borgmeieri Schmitz, P. litoralis Borgmeier, P. obtusus, P. nocens Borgmeier, and $P$. affinis Borgmeier at several sites in the provinces of Buenos Aires, Santa Fe, Chaco, Formosa, Corrientes, and Entre Ríos (Briano, unpublished data). Several sites with high densities of flies were used later to run field host preference tests. Five species of flies ( $P$. tricuspis, $P$. curvatus, $P$. litoralis, $P$. obtusus, and $P$. nocens) were shipped to the quarantine facilities at CMAVE for mass rearing, hostspecificity tests, and eventual field releases.

Later, surveys were extended to western Argentina, southern Bolivia, southern Paraguay, Uruguay, and central Chile $[29,30,100]$. Fourteen Pseudacteon species were collected from $52 \%$ of the 720 fire ants mounds examined at 146 sites: $P$. curvatus, $P$. litoralis, $P$. tricuspis, $P$. nocens, $P$. obtusus, $P$. cultellatus Borgmeier, P. nudicornis Borgmeier, P. borgmeieri, P. solenopsidis Schmitz, and Pseudacteon near obtusus (small biotype) were associated with $S$. invicta. Nine species were sympatric at one site in Corrientes.

Pseudacteon obtusus showed the southernmost geographical distribution in Corralito, Río Negro, Argentina (Figure $1 ; 40^{\circ} 44^{\prime} \mathrm{S}$ ), and the westernmost in Bulnes, Bio Bio, Chile (Figure $1 ; 72^{\circ} 20^{\prime} \mathrm{W}$ ), where it was recorded attacking Solenopsis gayi (Spinola) and Solenopsis weyrauchi in Santa Cruz (Figure 1; 2,280 m), Tucumán province, Prepuna bioregion. Pseudacteon curvatus was one of the most abundant and widely distributed species. Its density was negatively correlated with the densities of $P$. obtusus and P. tricuspis $[30,101]$, suggesting differential habitat/host preferences and/or competitive replacement. Pseudacteon cultellatus was found attacking $S$. invicta in a gallery forest gap next to the Río Paraná, in Corrientes province [100]. A total of 356 P. tricuspis and 204 P. obtusus males were collected from disturbed fire ant mounds while chasing females for mating, showing sex ratios female : male of $2: 1$ and $1: 1$, respectively [30].
These ratios were similar to those observed in the laboratory at CMAVE (S. Porter, pers. comm.). However, the primary field sex ratio remained unknown.

A new species, $P$. calderensis Calcaterra, was discovered attacking the fire ant $S$. interrupta in Salta and Jujuy provinces $[100,102]$, a region scarcely surveyed after the last fire ant decapitating fly was discovered in South America [103].

Phenology and Phylogeny. Seasonal activity of phorid flies was studied at two S. invicta sites in Corrientes [104]. Species showed different annual and/or daily activity patterns. The highest abundance was recorded in spring and the lowest in summer. Abundance was higher close to dusk, and species diversity was highest at midday. Weather conditions affected the presence and abundance of most species except $P$. litoralis and $P$. nocens, which represented $71-79 \%$ of all female flies captured at these two sites in Corrientes. These flies were genetically very similar and showed similar patterns, suggesting a shared derived trait from a recent common ancestor. In contrast, $P$. cultellatus and P. nudicornis were genetically quite similar but showed different activity patterns [104].

Natural Parasitism and Detrimental Effect. Studies on natural parasitism conducted at multiple sites in northeastern Argentina revealed a very low overall rate of $0.2-0.5 \%$ worker parasitism. The highest rates per site $(1.2 \%)$ and per colony $(2.8 \%)$ were reported for a gallery forest in spring [104].

The presence of phorids affected the foraging capacity of S. invicta. A $50 \%$ decrease in the numbers of workers baited after the arrival of the flies suggests a potential shift in the use of food resources in favor of other ant species. However, an effect on the hierarchy of dominance of the ant assemblage was not observed [39].

Vectors. Using PCR techniques, Pseudacteon flies from Argentina were tested in the United States for their potential as vectors of the bacterium Wolbachia [105]. Seven of ten species tested were positive for four Wolbachia strains. Multiple infections were detected only in P. curvatus. Strains infecting the flies were not closely related to the sequences obtained from strains infecting S. invicta and S. richteri, indicating that these flies were not vectoring Wolbachia into these fire ant species. Pseudacteon decapitating flies do not appear to vector fire ant viruses [106].

More recently, Pseudacteon flies were tested as potential vectors of the microsporidia $K$. solenopsae and $V$. invictae [107]. Several species of flies that were reared from S. invictainfected workers were confirmed as carriers of $K$. solenopsae. Detrimental effects on the development of fly pupae and on emergence of adult flies were not observed. These results indicated that Pseudacteon flies might vector K. solenopsae but actual vectoring remains to be confirmed. In contrast, $V$. invictae did not infect phorids reared from infected fire ants [107].

Field Releases in the United States. In 1995, the first releases of $P$. tricuspis from South America (without the participation/collaboration of SABCL) were conducted in Texas by 
scientists of the University of Texas at Austin. Later, other releases of $P$. curvatus and P. obtusus were conducted by the Texas Cooperative Extension Program in collaboration with APHIS and ARS [108]. The establishment and expansion of the flies have been systematically monitored [109-111].

Since 1997, five Pseudacteon species have been released by CMAVE researchers. These species and biotypes are those originally found in Brazil and Argentina and later tested in the US and/or in South America by CMAVE scientists with close collaboration of Brazilian and SABCL researchers. The species released are (1) P. tricuspis, biotype São Paulo, Brazil, released from 1997 to 2000 [112]; (2) P. curvatus, biotype Las Flores, Argentina, released in 2000 [113]; (3) P. curvatus, biotype Formosa, Argentina, released in 2003 [114]; (4) P. litoralis, biotype Formosa, released in 2005 [115]; (5) P. obtusus, biotype Formosa, released in 2008 (Porter, unpublished data); (6) P. cultellatus, biotype Corrientes, released in 2010 (Porter, in progress).

Several postrelease studies were conducted in the United States mainly on $P$. tricuspis and P. curvatus. These studies (1) confirmed predictions of the high host specificity of the pre-release studies $[116,117],(2)$ documented their establishment and spread [108, 109, 118, 119], (3) documented seasonal abundance and rates of parasitism [120], and (4) indicated little detrimental effect of P. tricuspis on S. invicta population densities [121]. Other studies on distribution and efficacy are in progress.

\subsubsection{Eucharitid Wasps}

Biology. Almost all species of the small wasps, Orasema spp. (Hymenoptera: Eucharitidae), are brood parasites of myrmicine ants in the genera Pheidole, Solenopsis, Tetramorium, and Wasmannia [24, 122-124]. Adult females lay their eggs into host plants, and the emerging larvae (planidia) attach themselves to foraging ant hosts and are carried into the nest $[123,125]$. Adult wasps of O. simplex Heraty showed a short life span in the laboratory, estimated in $3.6 \pm 1.5$ days, and a single female had more than 600 mature oocytes in the ovarioles indicating a high fertility at emergence [126]. The short female survivorship and high fertility strongly suggested that $O$. simplex is a proovigenic species, representing a way to counteract the low probability of the phoretic transport provided by foraging worker ants to reach the nest.

Occasional observations reported several types of plant tissues as oviposition sites [122, 127-130]. Recent laboratory nonchoice oviposition tests with plants of economic and ornamental importance such as corn, soybeans, lemon, red pepper, and Vinca rosea confirmed that all plants tested resulted appropriate substrates for oviposition [126].

Similarly, field observations in the surroundings of parasitized fire ant colonies located at three sites in the provinces of Corrientes and Entre Ríos revealed that $87 \%$ of the shrubs and grasses present in the genera Smilax, Paspalum, Grindelia, Eupatorium, Sesbania, Asclepias, Verbena, Sida, and Stemodia showed oviposition marks [126].

While associated with the brood, immature Orasema species produce or assimilate compounds that mimic the cuticular hydrocarbon profile of the ant host, thus avoiding detection [131]. Pupation occurs in the brood, followed by adult emergence within the ant nest. The adults exit the nest for mating and oviposition $[125,132]$ (Figure 8).

Surveys. Fifty-five species of Orasema have been described worldwide $[124,133]$, and more than 200 species have been estimated for the Neotropic (Heraty, pers. comm.). Orasema parasitoids were first reported on fire ants of the S. saevissima complex in Uruguay [134]; O. xanthopus (Cameron) was later found parasitizing up to $40 \%$ of the colonies of $S$. invicta and other fire ant species of the same complex in Brazil [24, 25, 99, 135, 136]. In Argentina, 11 species were reported, three of which were parasitoids of fire ants in Buenos Aires, La Pampa, and some of the northwestern provinces $[123,137]$.

Between 2005 and 2007, the distribution of Orasema species and their ant hosts were intensively studied in Argentina and neighboring countries by excavating Solenopsis colonies in 73 sites in roadsides, pastures, and recreational areas [138]. A total of 731 colonies with brood were transported to the laboratory, separated from the soil by flotation [139] and the brood isolated [140] for Orasema individuals. Orasema was found in 29 sites parasitizing $13.5 \%$ of the 443 colonies in Argentina and $4.2 \%$ of the 288 colonies in Paraguay, Uruguay, and Bolivia. Five species were identified: (1) O. simplex was the most abundant, occurring at 17 sites and in $63.7 \%$ of the 72 parasitized colonies; (2) O. xanthopus and (3) O. salebrosa Heraty were found only at two sites; (4) O. aenea Gahan was found parasitizing fire ants for the first time at one site in Argentina; (5) O. pireta Heraty was found at one site parasitizing an unidentified Solenopsis species in Bolivia. In Paraguay and Uruguay, only O. simplex was present [138].

Two new host species of Orasema within the S. saevissima complex were discovered: S. quinquecuspis in Argentina and S. macdonaghi in Uruguay.

The wide variety of habitats and geographic distribution suggested that Orasema is a common parasitoid of fire ants in their native land. However, a second sampling of the Argentine sites conducted 6 to 18 months later revealed a field persistence in only $36.4 \%$ of the sites [138].

Laboratory Rearing. After several attempts and different approaches, the laboratory rearing and artificial transfer of this parasitoid to nonparasitized fire ants was achieved by placing planidia together with plant tissue in fragmented receptor colonies with abundant healthy brood [126]. However, this method had a very low success rate of $3.1 \%$ (only 12 adult wasps obtained from 385 planidia transferred). As previously observed by Vander Meer et al. [131], immature Orasema individuals were tended by ant workers as their own brood, with no aggression. However, several Orasema adults were found partially preyed, suggesting the loss of host-specific compounds soon after emergence.

\subsubsection{Myrmecolacid Strepsipteran}

Life Cycle. The ant parasitoid, Caenocholax fenyesi Pierce (Strepsiptera: Myrmecolacidae), has an unusual life cycle in 


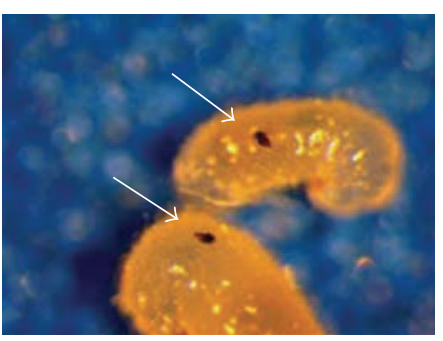

(a)

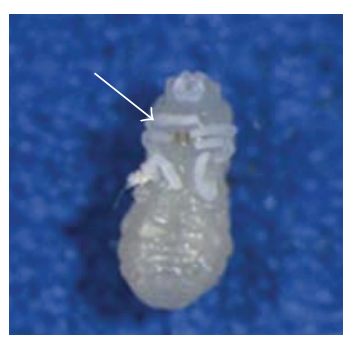

(b)

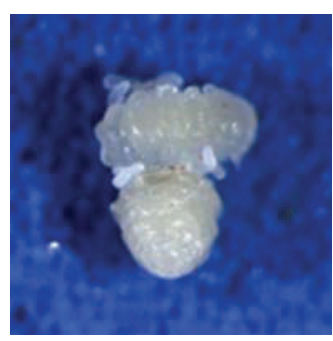

(c)

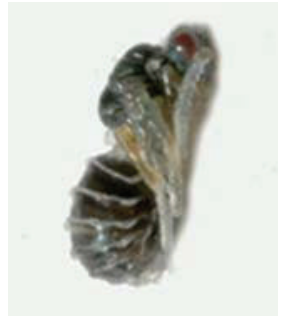

(d)

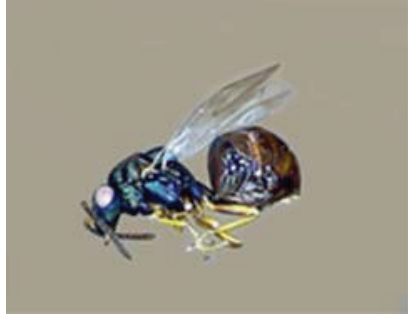

(e)

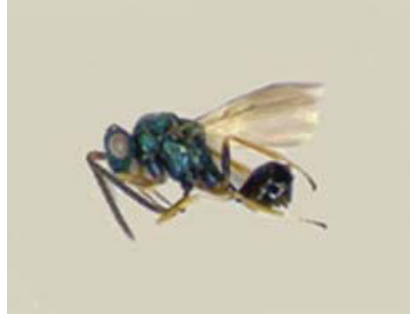

(f)

Figure 8: Life cycle of Orasema. (a) Planidia (arrows) attached to ant larvae. (b) First-instar larva (arrow). (c) Developed larva (ant larva behind). (d) Pupa. (e) Adult female. (f) Adult male.

which males parasitize ants while females parasitize crickets $[141,142]$; it is currently the only extant species in its genus. The male of this species has the smallest genome $(108 \mathrm{Mb})$ studied so far [143]. The lack of information on its host associations has led to several speculations.

Distribution and Hosts. Caenocholax fenyesi has a wide geographical distribution occurring from southern United States to Chile and Argentina and infects seven ant species from three subfamilies with discontinuous distributions [144-146]. In Mexico, Central America, or Ecuador where $S$. invicta did not occur, $C$. fenyesi parasitized other ant species [147]. Males of $C$. fenyesi had been previously collected in Salta province in northwestern Argentina where mtDNA haplotypes of S. invicta occur [31, 145].

Parasitoid-Host Association. In 2003-2004, 15 C. fenyesi males were isolated in the laboratory from four S. invicta colonies originally collected in Corrientes and Formosa provinces. This was the first report of $C$. fenyesi parasitizing $S$. invicta in South America [144]. However, the parasitism rate was less than $0.2 \%$. In 2003 and 2005, additional surveys for C. fenyesi females using light traps, pitfall traps, and sweep nets were conducted in areas of Corrientes and Formosa where parasitized $S$. invicta colonies have been found previously. None of the 456 orthopterans, 9 dyctiopterans (Mantodea), and 6 phasmodeans (Proscopidae) collected were parasitized by C. fenyesi [144].

Cryptic Diversity. Recent molecular analysis revealed that C. fenyesi contained at least 10 cryptic lineages consistent with separate species and that the genetic diversity was strongly structured by geography and host association of the female [147]. Further studies revealed slight variation in key morphological characters, so several species might not be strictly cryptic (J. Kathiritamby, pers. comm.).

\subsection{Parasites}

\subsubsection{Social Parasitic Ant}

Life History. Only one social parasite, the parasitic ant Solenopsis (=Labauchena) daguerrei, has been effectively reported for fire ants [148]. Like most other social inquilines, S. daguerrei has lost the worker caste and produces only reproductive queens and males [149] with a numerical sex ratio female: male of $3: 1$ [149]. The parasite commandeers the host's workers to care for its own brood and provide them with food [150]. Mature parasite queens that have shed their wings (dealates) are only one-tenth the weight of fire ant host queens [149]; they attach or "yoke" themselves to the neck of the host queen with their mandibles and ride around on her back or sides (Figure 9).

A host queen may have two or three parasite queens attached to her neck and another half a dozen to other parts of her body, apparently intercepting food intended for the host queens and inhibiting host queen egg production $[149,150]$. Parasitic queens attached to hosts survived longer than those not attached [151].

Since the parasites are treated like nestmates by host workers, S. daguerrei apparently avoids the chemical recognition system of its hosts by mimicking or assimilating the cuticular hydrocarbons responsible for the host colony odor [150-152]. The ability of $S$. daguerrei to match host colony odor is likely to be sensitive to the strong patterns of genetic differentiation of the hosts, being consistent with the hypothesis that these parasites are locally adapted to their hosts, and thus specific to their associated host ecotype. 


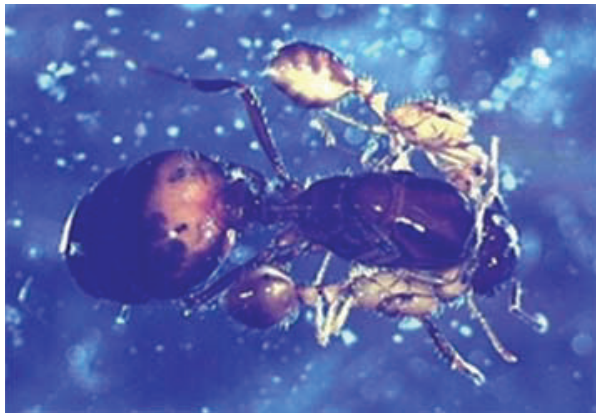

Figure 9: Two queens of Solenopsis daguerrei yoking a queen of Solenopsis richteri.

However, many laboratory and field attempts to artificially propagate this parasitic ant using sympatric colonies have failed [153]. Parasitized and nonparasitized colonies were used as source and receptor colonies, respectively. Several approaches were used, such as transference of parasitic queens, sexuals and/or pupae, contact of entire colonies, transplanting of entire field colonies, and the transfer of newly mated parasitic queens.

Field Surveys. Surveys for S. daguerrei in fire ant populations were conducted in Argentina, Brazil, Bolivia, Paraguay, and Uruguay by ARS scientists from 1974 to 1996 [154]. The examination of 12,180 fire ant colonies revealed occurrence of this parasitic ant in a variety of habitats in northeastern Argentina, Uruguay, and southern Brazil. Parasitization occurred in S. richteri, S. quinquecuspis, S. invicta, S. macdonaghi, and S. saevissima, all members of the S. saevissima species group. The overall parasitism rates ranged from 1 to $7 \%$ of the colonies. The sites with the highest parasitism rates were San Eladio, Buenos Aires, Argentina, with $7 \%$ and Dourados, Mato Grosso do Sul, Brazil with 6,2\% (Figure 1). However, surveys in the 1970s revealed that in some localities S. daguerrei was found in $24-70 \%$ of the colonies $[59,150]$.

Phenology and Mating. Most of the available information on $S$. daguerrei phenology and breeding biology was reported from S. richteri host populations in Buenos Aires province, Argentina. Adults of $S$. daguerrei were more common in fallearly winter, contrasting with the low seasonality showed by parasitic populations in northern Argentina and southern Brazil [148]. Mating flights were not observed. In a laboratory study, a total of 756 individuals of $S$. daguerrei were captured flying out from S. richteri host colonies; of those, $738(98 \%)$ were females ( $87 \%$ were inseminated) and only $18(2 \%)$ were males [151]. A later examination of the host colonies showed that no parasitic males were found inside and that $40 \%$ of the parasitic females were inseminated. As previously suggested [150], these observations confirmed that copulation occurred mainly inside the nests with nestmates, resulting in a high level of inbreeding [155]. However, cryptic dispersal of males and mating with noninseminated females might occur, thereby reducing inbreeding. Also, the apparent poor dispersal ability of this parasite suggested a strong genetic differentiation on both a micro- and macrogeographic scale (Bouwma, unpublished data).

Detrimental Effect. Field studies conducted in the area of San Eladio in Argentina on S. richteri colonies [149, 156] showed that, compared to nonparasitized colonies, parasitized colonies (1) had less worker brood, (2) produced the sexual caste later in the season, and (3) had fewer queens ( 2.9 versus 5.5 ). This suggested that the parasite might drive the host toward monogyny. Also, in field populations of $S$. richteri, lower mound densities were found in areas with presence of the parasite compared to parasite-free sites, suggesting some potential for the biological control of fire ants. In a few laboratory studies, $S$. daguerrei was reported to kill the host queens by decapitation [148] and to cause the colony to collapse [150].

Evolutionary Traits. Like other social parasites, it is believed that $S$. daguerrei must be highly specialized and has evolved the ability to exploit the social system of their hosts [155]. Recent studies on the evolutionary history of members of the S. saevissima species group were based on morphological characters [1] and mtDNA sequences [157]. These studies showed that $S$. daguerrei occupied a basal position in the group and that it was a close relative of its several hosts. It belonged to a larger clade, sister of the host clade, following the loose version of Emery's rule [158] and indicating that S. daguerrei would not have evolved directly from their hosts within the S. saevissima group (strict version of Emery's rule) [159-162]. This is supported by the single origin of social parasitism suggested for $S$. daguerrei collected from S. invicta and S. richteri host colonies over a vast geographic area [157].

In 2007, molecular studies to determine the genetic structure of $S$. daguerrei in Argentina, southern Brazil, and Paraguay revealed a high genetic variability and the probable presence of a complex with new species (Bouwma, unpublished data).

Vectors. To test if $S$. daguerrei was a vector of the bacterium Wolbachia, three individuals of the parasitic ant were found to be infected representing a new host record for Wolbachia [105]. Sequence analyses revealed that each individual contained the unusual number of eight Wolbachia variants. In total, nine unique sequences or strains were found, two of which were identical to the sequences obtained from their fire ant hosts $S$. invicta and S. richteri. This suggested horizontal transmission of Wolbachia between S. daguerrei and its hosts.

\section{Conclusions}

Native fire ants in southern South America, mainly $S$. invicta, were dominant ants in several regions, but these ant communities usually included several abundant competitors. This strong competitive environment in their homeland contrasts with the situation in invaded communities in North America. The release from interspecific competition in the new habitats and the escape from coevolved natural enemies seem to strongly contribute to $S$. invicta's successful invasions in North America. 
Since 1987, the field surveys and the examination of approximately 14,000 fire ant colonies in almost 1,000 collecting sites in Argentina and neighboring countries have documented the presence of the microsporidia Kneallhazia solenopsae and Vairimorpha invictae, the nematode Allomermis solenopsi, three $S$. invicta viruses, 14 species of Pseudacteon decapitating flies, 5 species of the parasitoid wasp Orasema, the strepsipteran Caenocholax fenyesi, and the parasitic ant Solenopsis daguerrei.

Kneallhazia solenopsae was the most common pathogen of native fire ants, showing a wide distribution and high field persistence, mainly infecting $S$. richteri. On the other hand, $V$. invictae showed a narrower distribution, a lower and disjunct overall occurrence, and higher prevalence in $S$. invicta. Both diseases showed the ability to infect monogyne and polygyne populations, and, at times and in certain areas, they reached epizootic levels, representing the highest infection rates ever reported for South America. Despite this, the natural occurrence of dual infections in the field was very low and similar to probability predictions (combined probability of finding at random $K$. solenopsae and $V$. invictae simultaneously in the same colony).

Their high intracolonial prevalence indicated that these microsporidia were important chronic diseases of fire ants. Both diseases showed several deleterious effects on individual colonies and field populations, and their ecological and physiological host ranges were restricted to closely related ants in the genus Solenopsis. These facts suggested that they might be good self-sustaining organisms for the classical biological control of the imported fire ants in the United States, with little or no risk to native ants and other arthropods.

The horizontal transmission of both pathogens accomplished by CMAVE scientists in the United States has allowed specificity and efficacy trials under laboratory and field conditions. Once field release of $V$. invictae is approved for the United States, the ability to transmit this disease into $S$. invicta colonies will accelerate the artificial field infection, its dispersal, and the eventual faster decline in imported fire ant population densities.

The finding and identification of the nematode $A$. solenopsi represented a new species discovery. The overall occurrence was low, and the parasitism rates in the field were highly variable. Laboratory rearing was difficult, and many aspects of its life cycle remain unknown. However, infected fire ants showed shorter longevity and interesting changes in their behavior. Further efforts with this organism are recommended.

The use of molecular techniques facilitated the screening for fire ant viruses. Of the three viruses found, SINV-1 was the most common and abundant and was frequently found in combination with the other two. Although no detrimental effect was observed in field infected colonies in the United States, under certain stress conditions, colonies might collapse. Consequently, a combination of these viruses and their genetic manipulation represent a potential alternative to traditional insecticides for controlling imported fire ants.

Among the parasitoids, by far, Pseudacteon flies were the most frequent and abundant, with 14 species collected, many of which were sympatric. Pseudacteon curvatus was the most abundant in many areas followed by P. obtusus, one of the most widely distributed. However, the overall natural parasitism rate was very low, indicating low direct effect on worker mortality. As expected, the presence of phorids decreased the foraging capacity of the workers. A new species was discovered, and several new fire ant hosts were documented. Many of the species exhibited different annual and daily activity patterns, and some of them showed the possibility of vectoring K. solenopsae.

Five Pseudacteon species were released by ARS in the United States. Several postrelease studies documented their establishment, spread, seasonal abundance, and parasitism rates and confirmed their high specificity for the imported fire ants. Unfortunately, significant reductions of S. invicta population densities have not been observed yet.

A considerable amount of new information on the biology of Orasema wasps was obtained. Their overall occurrence was fairly high, and they were found in many habitats over a wide geographic range. In addition, five species were identified and two new Solenopsis hosts were discovered. The laboratory rearing and artificial transmission was obtained for the first time but at very low rates. A wide variety of economically important plants were confirmed as oviposition substrates. Cosmetic damage to many plants during the oviposition process probably precludes this organism from further testing for fire ant biological control.

Similarly, useful biological information was gathered for Caenocholax fenyesi mainly on its host associations. The finding of parasitism on S. invicta represented the first record in South America. However, parasitism rates were extremely low. In addition, preliminary attempts to elucidate its complicated life cycle by finding the females in the field have failed. At this point, the use of this organism as a biological control agent of fire ants seems very unlikely.

The parasitic ant $S$. daguerrei parasitizes several fire ant species within the S. saevissima group. The overall occurrence was low, but, in certain areas, it reached high parasitism rates, mainly on S. invicta in Brazil and S. richteri in Argentina. New biological observations were reported on phenology and mating, and several detrimental effects were documented for field populations of $S$. richteri. In addition, molecular studies on its evolutionary history revealed close host relatedness and wide genetic variability, suggesting the potential presence of a complex of species. Future studies on parasite-host matching are needed to identify the most suitable species or biotype for biological control of S. invicta in the US. Unfortunately, unsolved rearing problems and the inability to transfer this parasite to nonparasitized fire ant colonies have discouraged further testing.

In summary, after 23 years of intensive field work and laboratory research, the main objective of the program to find a complex of fire ant natural enemies and to evaluate their specificity and suitability for field release has, indeed, been accomplished. Many natural enemies were found, investigated, and developed in close collaboration with ARS scientists in the United States. Several of these organisms were field released, and their ecology and efficacy in the new habitats continue to be evaluated. Many of these biological 
control agents could be available for use in other countries or regions invaded by fire ants.

The pioneering studies conducted in South America on native fire ants and their natural enemies have served to greatly encourage further investigations by many scientists and institutions in the United States and other countries. These efforts have advanced the implementation of areawide biological control programs. Still, promising organisms such as V. invictae, S. daguerrei, A. solenopsi, viruses, and, maybe, more species or biotypes of Pseudacteon flies should be further investigated for eventual field release in the near future. It is expected that the final outcome of current and future programs will be the decrease of the imported fire ant population densities and their damage.

\section{Acknowledgments}

The authors thank all past and current ARS research leaders, scientists, and technicians at the Imported Fire Ants and Household Insects Unit in Gainesville, FL, for their continued support to initiate and codevelop the Imported Fire Ant Project in Argentina. Several scientists, D. P. Wojcik, D. P. Jouvenaz (deceased), R. S. Patterson, D. F. Williams, D. H. Oi, and S. D. Porter, have periodically visited SABCL and intensively collaborated on the progress of the project. Recent visits by S. M. Valles, A. Bowma, D. D. Shoemaker, and M. S. Ascunce have resulted in considerable molecular work. A number of local technicians and students, M. Carranza, J. Jara (deceased), A. Delgado, J. Livore, S. Cabrera, L. Ramírez, L. Nuñez, D. Iele, J. Sacco, and M. Manteca Acosta, assisted with field and lab work. They also thank very much David Oi and Sanford Porter for the critical review of this paper.

\section{References}

[1] J. P. Pitts, A cladistic analysis of the Solenopsis saevissima species-group (Hymenoptera: Formicidae), Ph.D. thesis, University of Georgia, Athens, Ga, USA, 2002.

[2] C. R. Thompson, "Ants that have pest status in the United States," in Applied Myrmecology: A World Perspective, R. K. Vander Meer, K. Jaffe, and A. Cedeño, Eds., pp. 51-67, Westview Press, Boulder, Colo, USA, 1990.

[3] W. F. Buren, "Revisionary studies on the taxonomy of the imported fire ants," Journal Georgia Entomological Society, vol. 7, pp. 1-26, 1972.

[4] S. Lowe, M. Browne, S. Boudjelas, and D. M. de Poorter, "100 of the World's Worst Invasive Alien Species", A selection from the Global Invasive Species Database, Invasive Species Specialist Group, Species Survival Commission, World Conservation Union, 2000.

[5] L. R. Davis, R. K. Vander Meer, and S. D. Porter, "Red imported fire ants expand their range across the West Indies," Florida Entomologist, vol. 84, no. 4, pp. 735-736, 2001.

[6] R. Nattrass and C. Vanderwoude, "A preliminary investigation of the ecological effects of red imported fire ants (Solenopsis invicta) in Brisbane, Australia," Ecological Management and Restoration, vol. 2, no. 3, pp. 220-223, 2001.

[7] A. Pascoe, "Turning up the heat on fire ants," Biosecurity Magazine, vol. 32, p. 6, 2001.

[8] X. J. Wang, "Red imported fire ant from South America invaded Taiwan causing panic; scholars in mainland China remind government of taking strict precautions against its invasion," Science Times, 2004.

[9] R. Zhang, Y. Li, N. Liu, and S. D. Porter, "An overview of the red imported fire ant (Hymenoptera: Formicidae) in mainland China," Florida Entomologist, vol. 90, no. 4, pp. 723-731, 2007.

[10] http://www.biosecurity.govt.nz/pests/red-imported-fire-ant.

[11] D. F. Williams, H. L. Collins, and D. H. Oi, “The red imported fire ant (Hymenoptera: Formicidae): an historical perspective of treatments programs and the development of chemical baits for control," American Entomologist, vol. 47, pp. 146$159,2001$.

[12] R. D. de Shazo, B. T. Butcher, and W. A. Banks, "Reactions to the stings of the imported fire ant," New England Journal of Medicine, vol. 323, no. 7, pp. 462-466, 1990.

[13] C. R. Allen, E. A. Forys, K. G. Rice, and D. P. Wojcik, "Are red imported fire ants a threat to hatching sea turtles?" in Proceedings of the Imported Fire Ant Research Conference, p. $115,1997$.

[14] C. R. Allen, K. G. Rice, D. P. Wojcik, and H. F. Percival, "Effect of red imported fire ant envenomization on neonatal American alligators," Journal of Herpetology, vol. 31, no. 2, pp. 318-321, 1997.

[15] G. R. Camilo and S. A. Philips, "Evolution of ant communities in response to invasion by the fire ant Solenopsis invicta," in Applied Myrmecology: A World Perspective, R. K. Vander Meer, K. Jaffe, and A. Cedeño, Eds., pp. 190-198, Westview Press, Boulder, Colo, USA, 1990.

[16] S. D. Porter and D. A. Savignano, "Invasion of polygyne fire ants decimates native ants and disrupts arthropod community," Ecology, vol. 71, no. 6, pp. 2095-2106, 1990.

[17] C. T. Adams, "Agricultural and medical impact of the imported fire ants," in Fire Ants and Leaf-Cutting Ants: Biology and Management, C. S. Lofgren and R. K. Vander Meer, Eds., pp. 48-57, Westview Press, Boulder, Colo, USA, 1986.

[18] S. B. Vinson and W. P. Mackay, "Effects of the fire ant Solenopsis invicta on electrical circuits and equipment," in Applied Myrmecology: A World Perspective, R. K. Vander Meer and A. Cedeño, Eds., pp. 496-503, Westview Press, Boulder, Colo, USA, 1990.

[19] T. E. Macom and S. D. Porter, "Comparison of polygyne and monogyne red imported fire ant (Hymenoptera: Formicidae) population densities," Annals of the Entomological Society of America, vol. 89, no. 4, pp. 535-543, 1996.

[20] W. R. Tschinkel, The Fire Ants, Belknap Press, Cambridge, Mass, USA, 2006.

[21] C. S. Lofgren, "History of imported fire ants in the United States," in Fire Ants and Leaf-Cutting Ants: Biology and Management, C. S. Lofgren and R. K. Vander Meer, Eds., pp. 36-47, Westview, Boulder, Colo, USA, 1986.

[22] G. E. Allen and W. F. Buren, "Microsporidian and fungal diseases of S. invicta Buren in Brazil," Journal of the New York Entomological Society, vol. 82, pp. 125-130, 1974.

[23] G. E. Allen and A. S. Guido, "Occurrence of microsporidia in Solenopsis invicta and Solenopsis sp. in Uruguay and Argentina," Florida Entomologist, vol. 57, pp. 327-329, 1974.

[24] R. N. Williams and W. H. Whitcomb, "Parasites of fire ants in South America," in Proceedings of the Annual Tall Timbers Conference on Ecological Animal Control by Habitat Management, vol. 5, pp. 49-59, 1974.

[25] D. P. Wojcik, "Survey for biocontrol agents in Brazil: a final report, with comments on preliminary research in 
Argentina," in Proceedings of the Imported Fire Ant Conference, pp. 50-62, Athens, Ga, USA, 1988.

[26] K. L. Hays, "The present status of the imported fire ant in Argentina," Journal of Economic Entomology, vol. 51, pp. 111$112,1958$.

[27] N. Kusnezov, Hormigas Argentinas: Clave para su Identificación, Fundación Miguel Lillo, Tucumán, Argentina, 1978.

[28] J. C. Trager, "A revision of the fire ants, Solenopsis geminata group (Hymenoptera: Formicidae: Myrmicinae)," Journal of the New York Entomological Society, vol. 99, pp. 141-198, 1991.

[29] L. A. Calcaterra, R. K. Vander Meer, J. P. Pitts, J. P. Livore, and N. D. Tsutsui, "Survey of Solenopsis fire ants and their parasitoid flies (Diptera: Phoridae: Pseudacteon spp.) in Central Chile and Central Western Argentina," Annals of the Entomological Society of America, vol. 100, no. 4, pp. 512-521, 2007.

[30] L. A. Calcaterra, Distribución y abundancia de la hormiga colorada Solenopsis invicta en Argentina: sus interacciones con hormigas competidoras y moscas parasitoides (Pseudacteon spp.), Doctoral Dissertation, Universidad de Buenos Aires, Buenos Aires, Argentina, 2010.

[31] M. S. Ascunce, C. Yang, J. Oakey et al., "Global invasion history of the fire ant Solenopsis invicta," Science, vol. 331, pp. 1066-1068, 2011.

[32] S. D. Porter, D. F. Williams, R. S. Patterson, and H. G. Fowler, "Intercontinental differences in the abundance of Solenopsis fire ants (Hymenoptera: Formicidae): escape from natural enemies?" Environmental Entomology, vol. 26, no. 2, pp. 373384, 1997.

[33] D. P. Jouvenaz, W. A. Banks, and J. D. Atwood, "Incidence of pathogens in fire ants, Solenopsis spp. in Brazil," Florida Entomologist, vol. 63, pp. 345-346, 1980.

[34] D. P. Jouvenaz, "Natural enemies of fire ants," Florida Entomologist, vol. 66, pp. 111-121, 1983.

[35] D. P. Jouvenaz, "Diseases of fire ants: problems and opportunities," in Fire Ants and Leaf-Cutting Ants: Biology and Management, C. S. Lofgren and R. K. Vander Meer, Eds., pp. 327-338, Westview, Boulder, Colo, USA, 1986.

[36] D. F. Williams, D. H. Oi, S. D. Porter, R. M. Pereira, and J. A. Briano, "Biological control of imported fire ants (Hymenoptera: Formicidae)," American Entomologist, vol. 49, pp. 150-163, 2003.

[37] P. J. Folgarait, P. D’adamo, and L. E. Gilbert, "A grassland ant community in Argentina: the case of Solenopsis richteri and Camponotus punctulatus (Hymenoptera: Formicidae) attaining high densities in their native ranges," Annals of the Entomological Society of America, vol. 97, no. 3, pp. 450-457, 2004.

[38] E. G. LeBrun, C. V. Tillberg, A. V. Suarez, P. J. Folgarait, C. R. Smith, and D. A. Holway, "An experimental study of competition between fire ants and Argentine ants in their native range," Ecology, vol. 88, no. 1, pp. 63-75, 2007.

[39] L. A. Calcaterra, J. P. Livore, A. Delgado, and J. A. Briano, "Ecological dominance of the red imported fire ant, Solenopsis invicta, in its native range," Oecologia, vol. 156, no. 2, pp. 411-421, 2008.

[40] D. H. Feener Jr, M. R. Orr, K. M. Wackford, J. M. Longo, W. W. Benson, and L. E. Gilbert, "Geographic variation in resource dominance discovery in Brazilian ant communities," Ecology, vol. 89, no. 7, pp. 1824-1836, 2008.

[41] L. A. Calcaterra, F. Cuezzo, S. M. Cabrera, and J. A. Briano, "Ground ant diversity in the Iberá natural reserve: the largest wetland of Argentina," Annals of the Entomological Society of America, vol. 103, no. 1, pp. 71-83, 2010.

[42] L. A. Calcaterra, S. M. Cabrera, F. Cuezzo, I. J. Perz, and J. A. Briano, "Habitat and grazing influence on terrestrial ants in subtropical grasslands and savannas of Argentina," Annals of the Entomological Society of America, vol. 103, no. 4, pp. 635-646, 2010.

[43] E. J. Caldera, K. G. Ross, C. J. DeHeer, and D. D. Shoemaker, "Putative native source of the invasive fire ant Solenopsis invicta in the USA," Biological Invasions, vol. 10, no. 8, pp. 1457-1479, 2008.

[44] G. E. Allen, W. F. Buren, R. N. Williams, M. de Menezes, and W. H. Whitcomb, "The red imported fire ant, Solenopsis invicta: distribution and habitat in Mato Grosso, Brazil," Annals of the Entomological Society of America, vol. 67, pp. 43-46, 1974.

[45] J. D. Knell, G. E. Allen, and E. I. Hazard, "Light and electron microscope study of Thelohania solenopsae n. sp. (Microsporida: Protozoa) in the red imported fire ant, Solenopsis invicta," Journal of Invertebrate Pathology, vol. 29, no. 2, pp. 192-200, 1977.

[46] D. P. Jouvenaz and E. A. Ellis, "Vairimorpha invictae n. sp. (Microspora: Microsporida), a parasite of the red imported fire ant, Solenopsis invicta Buren (Hymenoptera: Formicidae)," Journal of Protozoology, vol. 33, no. 4, pp. 457-461, 1986.

[47] Y. Sokolova and J. R. Fuxa, "Development of Thelohania solenopsae in red imported fire ants Solenopsis invicta from polygynous colonies results in formation of three spore types," in Proceedings of the 7th International Workshops on Opportunistic Protists, vol. 58S, Cincinnati, Ohio, USA, 2001.

[48] Y. Y. Sokolova, L. R. Mcnally, and J. R. Fuxa, "PCR-based analysis of apores isolated from smears by laser pressure catapult microdissection confirms genetic identity of spore morphotypes of the microsporidian Thelohania solenopsae," Journal of Eukaryotic Microbiology, vol. 50, pp. 584-585, 2003.

[49] Y. Y. Sokolova, L. R. McNally, J. R. Fuxa, and S. B. Vinson, "Spore morphotypes of Thelohania solenopsae (microsporidia) described microscopically and confirmed by PCR of individual spores microdissected from smears by position ablative laser microbeam microscopy," Microbiology, vol. 150, no. 5, pp. 1261-1270, 2004.

[50] A. M. Shapiro, J. J. Becnel, D. H. Oi, and D. F. Williams, "Ultrastructural characterization and further transmission studies of Thelohania solenopsae from Solenopsis invicta pupae," Journal of Invertebrate Pathology, vol. 83, no. 2, pp. 177-180, 2003.

[51] J. A. Briano, Effect of the pathogen Thelohania sp. (Microsporida: Thelohaniidae) on field populations of the fire ant Solenopsis richteri (Hymenoptera: Formicidae) in Argentina, M.S. thesis, University of Florida, Gainesville, Fla, USA, 1993.

[52] J. A. Briano, D. P. Jouvenaz, D. P. Wojcik, H. A. Cordo, and R. S. Patterson, "Protozoan and fungal disease in Solenopsis richteri and S.quionquecuspis (Hymenoptera: Formicidae) in Buenos Aires province, Argentina," Florida Entomologist, vol. 78, no. 3, pp. 531-537, 1995.

[53] J. A. Briano and D. F. Williams, "Natural occurrence and laboratory studies of the fire ant pathogen Vairimorpha invictae (Microsporida: Burenellidae) in Argentina," Environmental Entomology, vol. 31, no. 5, pp. 887-894, 2002.

[54] S. M. Valles and J. A. Briano, "Presence of Thelohania solenopsae and Vairimorpha invictae in South American 
populations of Solenopsis invicta," Florida Entomologist, vol. 87, no. 4, pp. 625-627, 2004.

[55] J. A. Briano, R. S. Patterson, and H. A. Cordo, "Relationship between colony size of Solenopsis richteri (Hymenoptera: Formicidae) and infection with Thelohania solenopsae (Microsporida: Thelohaniidae) in Argentina," Journal of Economic Entomology, vol. 88, pp. 1233-1237, 1995.

[56] D. F. Williams, G. J. Knue, and J. J. Becnel, "Discovery of Thelohania solenopsae from the red imported fire ant, Solenopsis invicta, in the United States," Journal of Invertebrate Pathology, vol. 71, no. 2, pp. 175-176, 1998.

[57] J. A. Briano, L. A. Calcaterra, R. Vander Meer, S. M. Valles, and J. P. Livore, "New survey for the fire ant microsporidia Vairimorpha invictae and Thelohania solenopsae in southern South America, with observations on their field persistence and prevalence of dual infections," Environmental Entomology, vol. 35, no. 5, pp. 1358-1365, 2006.

[58] J. A. Briano, R. S. Patterson, J. J. Becnel, and H. A. Cordo, "The black imported fire ant, Solenopsis richteri, infected with Thelohania solenopsae: intracolonial prevalence of infection and evidence for transovarial transmission," Journal of Invertebrate Pathology, vol. 67, no. 2, pp. 178-179, 1996.

[59] R. S. Patterson and J. A. Briano, "Potential of three biological control agents for suppression of Solenopsis invicta, the red imported fire ant," in Proceedings of the 1st International Conference on Insect Pests in Urban Environments, pp. 35-43, Exeter, UK, 1993.

[60] J. A. Briano, R. S. Patterson, and H. A. Cordo, "Longterm studies of the black imported fire ant (Hymenoptera: Formicidae) infected with a microsporidium," Environmental Entomology, vol. 24, no. 5, pp. 1328-1332, 1995.

[61] J. A. Briano, R. S. Patterson, and H. A. Cordo, "Colony movement of the black imported fire ant (Hymenoptera: Formicidae) in Argentina," Environmental Entomology, vol. 24, no. 5, pp. 1131-1134, 1995.

[62] J. A. Briano and D. F. Williams, "Effect of the microsporidium Thelohania solenopsae (Microsporida: Thelohaniidae) on the longevity and survival of Solenopsis richteri (Hymenoptera: Formicidae) in the laboratory," Florida Entomologist, vol. 80, no. 3, pp. 366-376, 1997.

[63] J. A. Briano, "Long-term studies of the red imported fire ant, Solenopsis invicta, infected with the microsporidia Vairimorpha invictae and Thelohania solenopsae in Argentina," Environmental Entomology, vol. 34, no. 1, pp. 124-132, 2005.

[64] D. F. Williams, D. H. Oi, and G. J. Knue, "Infection of red imported fire ant (Hymenoptera: Formicidae) colonies with the entomopathogen Thelohania solenopsae (Microsporidia: Thelohaniidae)," Journal of Economic Entomology, vol. 92, no. 4, pp. 830-836, 1999.

[65] D. H. Oi, J. J. Becnel, and D. F. Williams, "Evidence of intracolony transmission of Thelohania solenopsae (Microsporidia: Thelohaniidae) in red imported fire ants (Hymenoptera: Formicidae) and the first report of spores from pupae," Journal of Invertebrate Pathology, vol. 78, no. 3, pp. 128-134, 2001.

[66] D. H. Oi and D. F. Williams, "Thelohania solenopsae (Microsporidia: Thelohaniidae) infection in reproductives of red imported fire ants (Hymenoptera: Formicidae) and its implication for intercolony transmission," Environmental Entomology, vol. 32, no. 5, pp. 1171-1176, 2003.

[67] D. H. Oi, J. A. Briano, S. M. Valles, and D. F. Williams, “Transmission of Vairimorpha invictae (Microsporidia: Burenellidae) infections between red imported fire ant (Hymenoptera:
Formicidae) colonies," Journal of Invertebrate Pathology, vol. 88, no. 2, pp. 108-115, 2005.

[68] J. A. Briano, D. F. Williams, D. H. Oi, and L. R. Davis, "Field host range of the fire ant pathogens Thelohania solenopsae (Microsporida: Thelohaniidae) and Vairimorpha invictae (Microsporida: Burenellidae) in South America," Biological Control, vol. 24, no. 1, pp. 98-102, 2002.

[69] M. S. Ascunce, S. M. Valles, D. H. Oi et al., "Molecular diversity of the microsporidium Kneallhazia solenopsae reveals an expanded host range among fire ants in North America," Journal of Invertebrate Pathology, vol. 105, no. 3, pp. 279-288, 2010.

[70] S. D. Porter, S. M. Valles, T. S. Davis et al., "Host specificity of the microsporidian pathogen Vairimorpha invictae at five field sites with infected Solenopsis invicta fire ant colonies in northern Argentina," Florida Entomologist, vol. 90, no. 3, pp. 447-452, 2007.

[71] D. H. Oi, S. M. Valles, and J. A. Briano, "Laboratory host specificity testing of the fire ant microsporidian pathogen Vairimorpha invictae (Microsporidia: Burenellidae)," Biological Control, vol. 53, no. 3, pp. 331-336, 2010.

[72] G. O. Poinar, S. D. Porter, S. Tang, and B. C. Hyman, "Allomermis solenopsi n. sp. (Nematoda: Mermithidae) parasitising the fire ant Solenopsis invicta Buren (Hymenoptera: Formicidae) in Argentina," Systematic Parasitology, vol. 68, no. 2, pp. 115-128, 2007.

[73] D. P. Jouvenaz and D. P. Wojcik, "Parasitic nematode observed in the fire ant Solenopsis richteri, in Argentina," Florida Entomologist, vol. 73, pp. 674-675, 1990.

[74] D. P. Wojcik, D. P. Jouvenaz, and R. S. Patterson, "Nematode parasites of fire ants from South America," in Proceedings of the Imported Fire Ants Conference, pp. 73-81, Stone Mountain Memorial Park, Atlanta, Ga, USA, 1991.

[75] G. O. J. Poinar and G. G. Gyfisco, "Studies on the bionomics of Hexamermis arvalis Poinar and Gyrisco, a mermithid parasite of the alfalfa weevil, Hypera postica (Gyllenhal)," Journal of Invertebrate Pathology, vol. 4, pp. 469-483, 1962.

[76] F. P. Cuthbert, "Bionomics of a mermithid (Nematode) parasite of soil-inhabiting larvae of certain chrysomelids (Coleoptera)," Journal of Invertebrate Pathology, vol. 12, no. 3, pp. 283-287, 1968.

[77] J. J. Petersen, "Biology of Octomyomermis muspratti, a parasite of mosquitoes as it relates to mass production," Journal of Invertebrate Pathology, vol. 30, no. 2, pp. 155-159, 1977.

[78] Y. Tanada and H. K. Kaya, Insect Pathology, Academic Press, San Diego, Calif, USA, 1993.

[79] J. J. Petersen, H. C. Chapman, and D. B. Woodard, "Preliminary observations on the incidence and biology of a mermithid nematode of Aedes sollicitans (Walker) in Louisiana," Mosquito News, vol. 27, pp. 493-498, 1967.

[80] J. Muspratt, "The laboratory culture of a nematode parasite of mosquito larvae," Journal of the Entomological Society of South Africa, vol. 10, pp. 131-132, 1947.

[81] J. J. Petersen and R. Willis, "Procedures for the mass rearing of a mermithid parasite of mosquitoes," Mosquito News, vol. 32, pp. 226-230, 1972.

[82] C. S. Creighton and G. Fassuliotis, "A laboratory technique for culturing Filipjevimermis leipsandra, a nematode parasite of Diabrotica balteata larvae (Insecta: Coleoptera)," Journal of Nematology, vol. 13, pp. 226-227, 1981.

[83] S. W. Avery, D. P. Jouvenaz, W. A. Banks, and D. W. Anthony, "Virus-like particles in a fire ant, Solenopsis sp., 
(Hymenoptera: Formicidae) from Brazil," Florida Entomologist, vol. 60, pp. 17-20, 1977.

[84] S. M. Valles, C. A. Strong, P. M. Dang et al., "A picorna-like virus from the red imported fire ant, Solenopsis invicta: initial discovery, genome sequence, and characterization," Virology, vol. 328, no. 1, pp. 151-157, 2004.

[85] S. M. Valles and C. A. Strong, "Solenopsis invicta virus-1A (SINV-1A): distinct species or genotype of SINV-1?" Journal of Invertebrate Pathology, vol. 88, no. 3, pp. 232-237, 2005.

[86] S. M. Valles, C. A. Strong, and Y. Hashimoto, "A new positivestrand RNA virus with unique genome characteristics from the red imported fire ant, Solenopsis invicta," Virology, vol. 365, no. 2, pp. 457-463, 2007.

[87] S. M. Valles, C. A. Strong, D. H. Oi et al., "Phenology, distribution, and host specificity of Solenopsis invicta virus1," Journal of Invertebrate Pathology, vol. 96, no. 1, pp. 18-27, 2007.

[88] Y. Hashimoto and S. M. Valles, "Infection characteristics of Solenopsis invicta virus 2 in the red imported fire ant, Solenopsis invicta," Journal of Invertebrate Pathology, vol. 99, no. 2, pp. 136-140, 2008.

[89] S. M. Valles and Y. Hashimoto, "Isolation and characterization of Solenopsis invicta virus 3, a new positive-strand RNA virus infecting the red imported fire ant, Solenopsis invicta," Virology, vol. 388, no. 2, pp. 354-361, 2009.

[90] D. H. Oi and S. M. Valles, "Fire ant control with entomopathogens in the USA," in Use of Microbes for Control and Eradication of Invasive Arthropods, A. E. Hajek, T. R. Glare, and M. O'Callaghan, Eds., pp. 237-258, Springer Science, New York, NY, USA, 2009.

[91] S. M. Valles, L. Varone, L. Ramírez, and J. Briano, "Multiplex detection of Solenopsis invicta viruses -1, -2, and -3," Journal of Virological Methods, vol. 162, no. 1-2, pp. 276-279, 2009.

[92] R. J. W. Patrock, S. D. Porter, L. E. Gilbert, and P. J. Folgarait, "Distributional patterns of Pseudacteon associated with the Solenopsis saevissima complex in South America," Journal of Insect Science, vol. 9, article 60, 2009.

[93] R. M. Plowes, E. G. Lebrun, B. V. Brown, and L. E. Gilbert, "A review of Pseudacteon (diptera: Phoridae) that parasitize ants of the Solenopsis geminata complex (hymenoptera: Formicidae)," Annals of the Entomological Society of America, vol. 102, no. 6, pp. 937-958, 2009.

[94] R. H. L. Disney, Scuttle Flies: The Phoridae, Chapman and Hall, London, UK, 1994.

[95] D. H. Feener Jr and B. V. Brown, "Diptera as parasitoids," Annual Review of Entomology, vol. 42, pp. 73-97, 1997.

[96] S. D. Porter and L. E. Gilbert, "Assessing host specificity and field release potential of fire ant decapitating flies (Phoridae: Pseudacteon)," in Assessing Host Ranges to Parasitoids and Predators Used for Classical Biological Control: A Guide to Best Practice, R. G. van Driesche, T. Murray, and R. Reardon, Eds., pp. 152-176, USDA Forest Service, Morgantown, WVa, USA, 2004.

[97] S. D. Porter and M. A. Pesquero, "Illustrated key to Pseudacteon decapitating flies (Diptera: Phoridae) that attack Solenopsis saevissima complex fire ants in South America," Florida Entomologist, vol. 84, no. 4, pp. 691-699, 2001.

[98] R. N. Williams, J. R. Panaia, D. Gallos, and W. H. Whitcomb, "Fire ants attacked by phorid flies," Florida Entomologist, vol. 56, pp. 259-262, 1973.

[99] R. N. Williams, "Insect natural enemies of fire ants in South America with several new records," in Proceedings of the Annual Tall Timbers Conference on Ecological Animal Control by Habitat Management, vol. 7, pp. 123-134, 1980.
[100] L. A. Calcaterra, S. D. Porter, and J. A. Briano, "Distribution and abundance of fire ant decapitating flies (Diptera: Phoridae: Pseudacteon spp.) in three regions of southern South America," Annals of the Entomological Society of America, vol. 98, no. 1, pp. 85-95, 2005.

[101] E. G. Lebrun, R. M. Plowes, and L. E. Gilbert, "Indirect competition facilitates widespread displacement of one naturalized parasitoid of imported fire ants by another," Ecology, vol. 90, no. 5, pp. 1184-1194, 2009.

[102] L. A. Calcaterra, "Pseudacteon calderensis, a new fly species (Diptera: Phoridae) attacking the fire ant Solenopsis interrupta (Hymenoptera: Formicidae) in northwestern Argentina," Annals of the Entomological Society of America, vol. 100, no. 4, pp. 470-473, 2007.

[103] B. V. Brown, P. Folgarait, and L. Gilbert, "A new species of Pseudacteon attacking Solenopsis fire ants (Hymenoptera: Formicidae) in Argentina," Sociobiology, vol. 41, no. 3, pp. 685-688, 2003.

[104] L. A. Calcaterra, A. Delgado, and N. D. Tsutsui, "Activity pattern of red imported fire ant decapitating flies (Diptera: Phoridae: Pseudacteon spp.) in northeastern Argentina," Annals of the Entomological Society of America, vol. 101, pp. 539-550, 2008

[105] F. Dedeine, M. Ahrens, L. Calcaterra, and D. D. Shoemaker, "Social parasitism in fire ants (Solenopsis spp.): a potential mechanism for interspecies transfer of Wolbachia," Molecular Ecology, vol. 14, no. 5, pp. 1543-1548, 2005.

[106] S. M. Valles and S. D. Porter, "Pseudacteon decapitating flies: potential vectors of a fire ant virus?" Florida Entomologist, vol. 90, no. 1, pp. 268-270, 2007.

[107] D. H. Oi, S. D. Porter, S. M. Valles, J. A. Briano, and L. A. Calcaterra, "Pseudacteon decapitating flies (Diptera: Phoridae): Are they potential vectors of the fire ant pathogens Kneallhazia (=Thelohania) Solenopsae (Microsporidia: Thelohaniidae) and Vairimorpha invictae (Microsporidia: Burenellidae)?” Biological Control, vol. 48, no. 3, pp. 310-315, 2009.

[108] R. M. Plowes, E. G. LeBrun, and L. E. Gilbert, "Introduction of the fire ant decapitating fly Pseudacteon obtusus in the United States: factors influencing establishment in Texas," BioControl, vol. 56, pp. 295-304, 2010.

[109] E. G. LeBrun, R. M. Plowes, and L. E. Gilbert, "Dynamic expansion in recently introduced populations of fire ant parasitoids (Diptera: Phoridae)," Biological Invasions, vol. 10, pp. 989-999, 2007.

[110] L. E. Gilbert, C. L. Barr, A. A. Calixto et al., "Introducing phorid fly parasitoids of red imported fire ant workers from South America to Texas: outcomes vary by region and by Pseudacteon species released," Southwestern Entomologist, vol. 33, no. 1, pp. 15-29, 2008.

[111] A. M. A. Callcott, S. D. Porter, R. D. Weeks Jr., L. C. Graham, S. J. Johnson, and L. E. Gilbert, "Fire ant decapitating fly cooperative release programs (1994-2008): two Pseudacteon species, P. tricuspis and P. curvatus, rapidly expand across imported fire ant populations in the southeastern United States," Journal of Insect Science, vol. 11, article 19, 2011.

[112] S. D. Porter, L. A. N. De Sa, and L. W. Morrison, "Establishment and dispersal of the fire ant decapitating fly Pseudacteon tricuspis in North Florida," Biological Control, vol. 29, no. 2, pp. 179-188, 2004.

[113] S. D. Porter, "Host specificity and risk assessment of releasing the decapitating fly Pseudacteon curvatus as a classical biocontrol agent for imported fire ants," Biological Control, vol. 19 , no. 1 , pp. $35-47,2000$. 
[114] R. J. Vazquez, S. D. Porter, and J. A. Briano, "Field release and establishment of the decapitating fly Pseudacteon curvatus on red imported fire ants in Florida," BioControl, vol. 51, no. 2, pp. 207-216, 2006.

[115] S. D. Porter, L. C. Graham, S. J. Johnson, L. G. Thead, and J. A. Briano, "The large decapitating fly Pseudacteon litoralis (Diptera: Phoridae): successfully established on fire ant populations in Alabama," Florida Entomologist, vol. 94, pp. 208-213, 2011.

[116] R. J. Vazquez and S. D. Porter, "RE-confirming host specificity of the fire ant decapitating fly Pseudacteon curvatus (Diptera: Phoridae) after field release in Florida," Florida Entomologist, vol. 88, no. 1, pp. 107-110, 2005.

[117] L. W. Morrison and S. D. Porter, "Post-release host-specificity testing of Pseudacteon tricuspis, a phorid parasitoid of Solenopsis invicta fire ants," BioControl, vol. 51, no. 2, pp. 195-205, 2006.

[118] R. M. Pereira and S. D. Porter, "Range expansion of the fire ant decapitating fly, $v$, eight to nine years after releases in North Florida," Florida Entomologist, vol. 89, no. 4, pp. 536538, 2006.

[119] D. C. Henne, S. J. Johnson, and S. D. Porter, "Status of the fire ant decapitating fly Pseudacteon tricuspis (Diptera: Phoridae) in Louisiana," Florida Entomologist, vol. 90, no. 3, pp. 565$569,2007$.

[120] L. W. Morrison and S. D. Porter, "Phenology and parasitism rates in introduced populations of Pseudacteon tricuspis, a parasitoid of Solenopsis invicta," BioControl, vol. 50, pp. 127$141,2005$.

[121] L. W. Morrison and S. D. Porter, "Testing for populationlevel impacts of introduced Pseudacteon tricuspis flies, phorid parasitoids of Solenopsis invicta fire ants," Biological Control, vol. 33, no. 1, pp. 9-19, 2005.

[122] J. B. Johnson, T. D. Miller, J. M. Heraty, and F. W. Merickel, "Observations on the biology of two species of Orasema (Hymenoptera: Eucahritidae)," Proceedings of the Entomological Society of Washington, vol. 88, pp. 542-549, 1986.

[123] J. M. Heraty, D. P. Wojcik, and D. P. Jouvenaz, "Species of Orasema parasitic on the Solenopsis saevissima-complex in South America (Hymenoptera: Eucharitidae, Formicidae)," Journal of Hymentopteran Research, vol. 2, pp. 169-182, 1993.

[124] J. M. Heraty, "Classification and evolution of the Oraseminae in the old world, including revision of two closely related genera of Eucharitinae (Hymenoptera: Eucharitidae)," Life Sciences Contributions, Royal Ontario Museum, vol. 157, 174 pages, 1994.

[125] C. P. Clausen, “The habits of the Eucharidae," Psyche, vol. 48, pp. 57-69, 1941.

[126] L. Varone and J. A. Briano, "Bionomics of Orasema simplex (Hymenoptera: Eucharitidae), a parasitoid of Solenopsis fire ants (Hymenoptera: Formicidae) in Argentina," Biological Control, vol. 48, no. 2, pp. 204-209, 2009.

[127] W. M. Wheeler, "The polymorphism of ants, with an account of some singular abnormalities due to parasitism," Bulletin of the American Museum of Natural History, vol. 23, pp. 1-93, 1907.

[128] C. P. Clausen, "The oviposition habits of the Eucharidae (Hymenoptera)," Journal of the Washington Academy of Sciences, vol. 30, pp. 504-516, 1940.

[129] H. L. Parker, "Oviposition habits and early stages of Orasema sp," Proceedings of the Entomological Society of Washington, vol. 44, pp. 142-145, 1942.
[130] A. Tocchetto, "Bicho costureiro," Revista da Agronomia, Porto Alegre, vol. 6, pp. 587-588, 1942.

[131] R. K. Vander Meer, D. P. Jouvenaz, and D. P. Wojcik, "Chemical mimicry in a parasitoid (Hymenoptera: Eucharitidae) of fire ants (Hymenoptera: Formicidae)," Journal of Chemical Ecology, vol. 15, no. 8, pp. 2247-2261, 1989.

[132] D. W. Johnson, "Eucharitidae (Hymenoptera: Chalcidoidea): biology and potential for biological control," Florida Entomologist, vol. 71, pp. 528-537, 1988.

[133] J. M. Heraty, "A revision of the Eucharitidae (Hymenoptera: Chalcidoidea) of the world," Memoirs of the American Entomological Institute, vol. 68, pp. 1-359, 2002.

[134] A. Silveria-Guido, P. San Martin, C. Crisci, and J. Carbonell, Investigations on the biology and biological control of the fire ant, Solenopsis saevissima richteri Forel in Uruguay, Third report, Departmento de Sanidad Vegetal, Facultad de Agronomía, Universidad de la República, Montevideo, Uruguay, 1964.

[135] D. P. Wojcik, D. P. Jouvenaz, and C. S. Lofgren, "First report of a parasitic fly (Diptera: Phoridae) from a red imported fire ant alate female (Hymenoptera: Formicidae)," Florida Entomologist, vol. 70, pp. 181-182, 1987.

[136] D. P. Wojcik, "Behavioral interactions between ants and their parasites," Florida Entomologist, vol. 72, pp. 43-51, 1989.

[137] J. M. Heraty, "Biology and importance of two eucharitid parasites of Wasmannia and Solenopsis," in Exotic Ants: Biology, Impact and Control of Introduced Species, pp. 104120, Westview Press, Boulder, Colo, USA, 1994.

[138] L. Varone, J. M. Heraty, and L. A. Calcaterra, "Distribution, abundance and persistence of species of Orasema (Hym: Eucharitidae) parasitic on fire ants in South America," Biological Control, vol. 55, no. 1, pp. 72-78, 2010.

[139] W. A. Banks, C. S. Lofgren, D. P. Jouvenaz et al., Techniques for Collecting, Rearing, and Handling Imported Fire Ants, USDA, SEA, AATS-S-21, 1981.

[140] D. H. Oi, D. F. Williams, R. M. Pereira et al., "Combining biological and chemical controls for the management of red imported fire ants (Hymenoptera: Formicidae)," American Entomologist, vol. 54, no. 1, pp. 44-53, 2008.

[141] J. L. Cook, S. B. Vinson, and R. E. Gold, "Developmental stages of Caenocholax fenyesi Pierce (Strepsiptera: Myrmecolacidae): descriptions and significance to the higher taxonomy of Strepsiptera," International Journal of Insect Morphology and Embryology, vol. 27, no. 1, pp. 21-26, 1998.

[142] J. Kathirithamby and J. S. Johnston, "The discovery after 94 years of the elusive female of a myrmecolacid (Strepsiptera), and the cryptic species of Caenocholax fenyesi Pierce sensu lato," Proceedings of the Royal Society of London, vol. 271, supplement 3, pp. S5-S8, 2004.

[143] J. S. Johnston, L. D. Ross, L. Beani, D. P. Hughes, and J. Kathirithamby, "Tiny genomes and endoreduplication in Strepsiptera," Insect Molecular Biology, vol. 13, no. 6, pp. 581585, 2004.

[144] J. L. Cook, L. A. Calcaterra, and L. Nuñez, "First record of Caenocholax fenyesi (Strepsiptera: Myrmecolacidae) parasitizing Solenopsis invicta (Hymenoptera: Formicidae) in Argentina, with a discussion on its distribution and host range," Entomological News, vol. 115, no. 2, pp. 61-66, 2004.

[145] J. Kathirithamby and D. P. Hughes, "Caenocholax fenyesi (Strepsiptera: Myrmecolacidae) parasitic in Camponotus planatus (Hymenoptera: Formicidae) in Mexico: is this the original host?" Annals of the Entomological Society of America, vol. 95 , no. 5, pp. 558-563, 2002. 
[146] J. Kathirithamby, "Host-parasitoid associations in Strepsiptera," Annual Review of Entomology, vol. 54, pp. 227-249, 2009.

[147] A. Hayward, D. P. McMahon, and J. Kathirithamby, "Cryptic diversity and female host specificity in a parasitoid where the sexes utilize hosts from separate orders," Molecular Ecology, vol. 20, pp. 1508-1528, 2011.

[148] C. Bruch, "Notas preliminares acerca de Labauchena daguerrei Santschi," Revista de la Sociedad Entomológica Argentina, vol. 3, pp. 73-82, 1930.

[149] L. A. Calcaterra, J. A. Briano, and D. F. Williams, "Field studies of the parasitic ant Solenopsis daguerrei (Hymenoptera: Formicidae) on fire ants in Argentina," Environmental Entomology, vol. 28, no. 1, pp. 88-95, 1999.

[150] A. Silveira-Guido, J. Carbonell, and C. Crisci, "Animals associated with the Solenopsis (fire ants) complex, with special reference to Labauchena daguerrei," in Proceedings of the Annual Tall Timbers Conference on Ecological Animal Control by Habitat Management, vol. 4, pp. 41-52, 1973.

[151] L. A. Calcaterra, J. A. Briano, D. F. Williams, and D. H. Oi, "Observations on the sexual castes of the fire ant parasite Solenopsis daguerrei (Hymenoptera: Formicidae)," Florida Entomologist, vol. 84, no. 3, pp. 446-448, 2001.

[152] M. F. Sledge, F. R. Dani, R. Cervo, L. Dapporto, and S. Turillazzi, "Recognition of social parasites as nest-mates: adoption of colony-specific host cuticular odors by the paper wasp parasite Polistes sulcifer," Proceedings of the Royal Society of London, Series B-Biological Sciences, vol. 268, pp. 22532260, 2001.

[153] J. A. Briano, L. A. Calcaterra, D. F. Williams, and D. H. Oi, "Attempts to artificially propagate the fire ant parasite Solenopsis daguerrei (Hymenoptera: Formicidae) in Argentina," Florida Entomologist, vol. 85, no. 3, pp. 518-520, 2002.

[154] J. A. Briano, L. A. Calcaterra, D. P. Wojcik, D. F. Williams, W. A. Banks, and R. S. Patterson, "Abundance of the parasitic ant, Solenopsis daguerrei (Hymenoptera: Formicidae) in South America, a potential candidate for the biological control of the red Imported fire ant in the United States," Environmental Entomology, vol. 26, no. 5, pp. 1143-1148, 1997.

[155] B. Hölldobler and E. O. Wilson, The Ants, Belknap Press, Cambridge, Mass, USA, 1990.

[156] L. A. Calcaterra, J. A. Briano, and D. F. Williams, "New host for the parasitic ant Solenopsis daguerrei (Hymenoptera: Formicidae) in Argentina," Florida Entomologist, vol. 83, no. 3, pp. 363-365, 2000.

[157] D. D. Shoemaker, M. E. Ahrens, and K. G. Ross, "Molecular phylogeny of fire ants of the Solenopsis saevissima speciesgroup based on mitochondrial DNA sequences," Molecular Phylogenetics and Evolution, vol. 38, no. 1, pp. 200-215, 2006.

[158] C. Emery, "Über den Ursprung der dulotischen, parasitischen und myrmekophilen Ameisen," Biologische Centralblatt, vol. 29, pp. 352-362, 1909.

[159] A. F. G. Bourke and N. R. Franks, "Alternative adaptations, sympatric speciation and the evolution of parasitic, inquiline ants," Biological Journal of the Linnean Society, vol. 43, no. 3, pp. 157-178, 1991.

[160] A. Buschinger, "Sympatric speciation and radiative evolution of socially parasitic ants-heretic hypotheses and their factual background," Zeitschrift Fur Zoologische Systematik Und Evolutionsforschung, vol. 28, pp. 241-260, 1990.

[161] R. Savolainen and K. Vepsäläinen, "Sympatric speciation through intraspecific social parasitism," Proceedings of the
National Academy of Sciences of the United States of America, vol. 100, no. 12, pp. 7169-7174, 2003.

[162] S. Sumner, D. K. Aanen, J. Delabie, and J. J. Boomsma, "The evolution of social parasitism in Acromyrmex leaf-cutting ants: a test of Emery's rule," Insectes Sociaux, vol. 51, no. 1, pp. 37-42, 2004. 

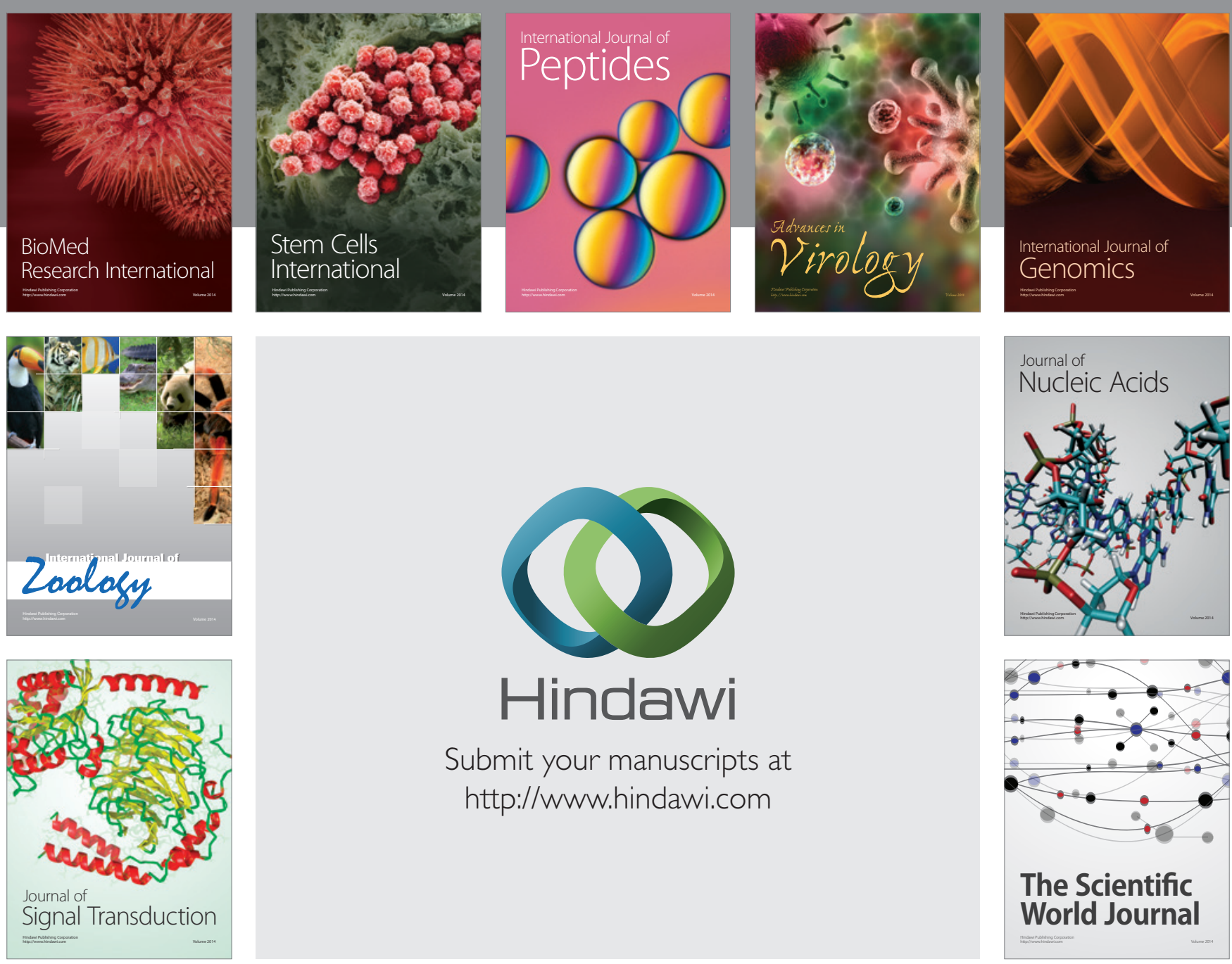

Submit your manuscripts at

http://www.hindawi.com
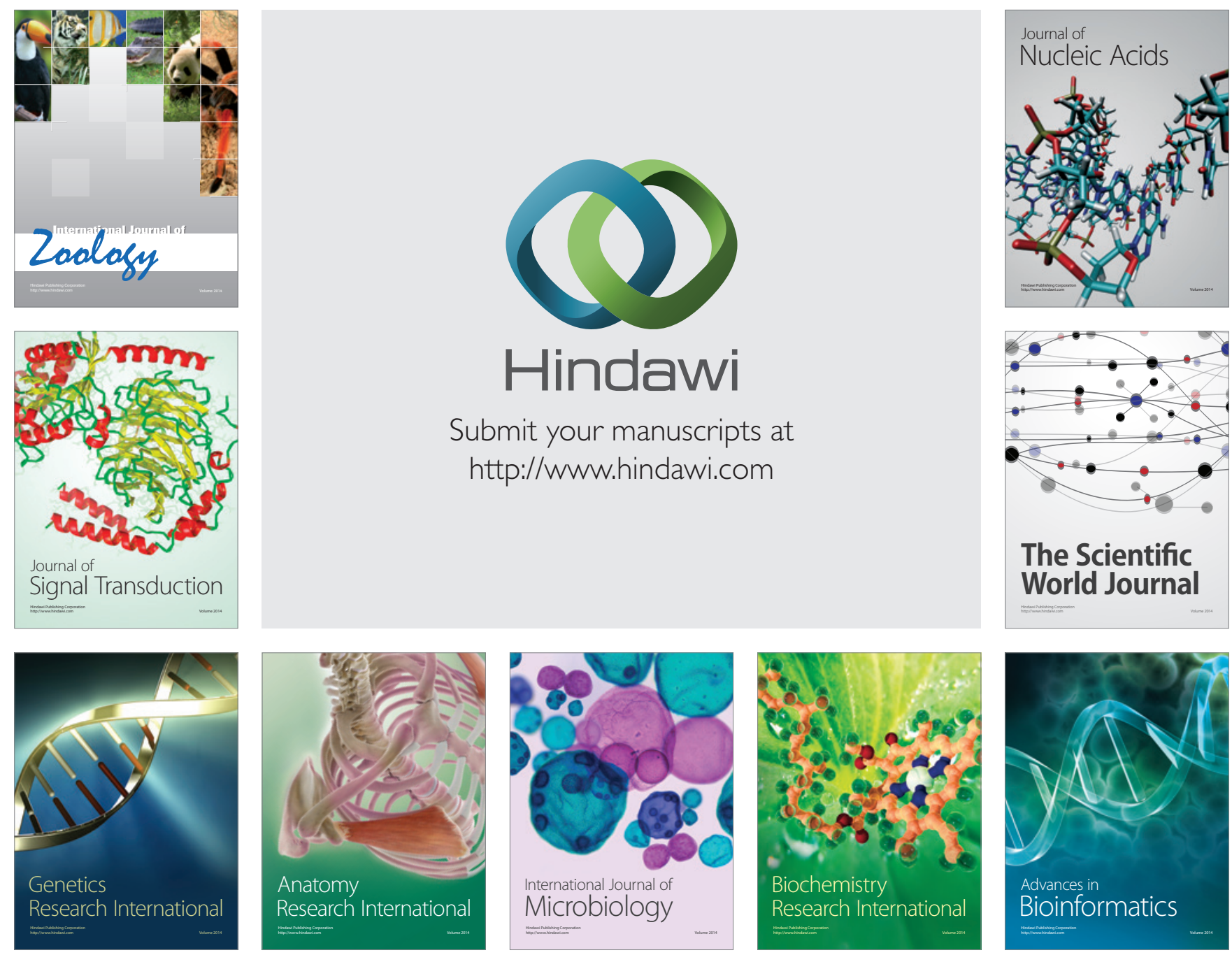

The Scientific World Journal
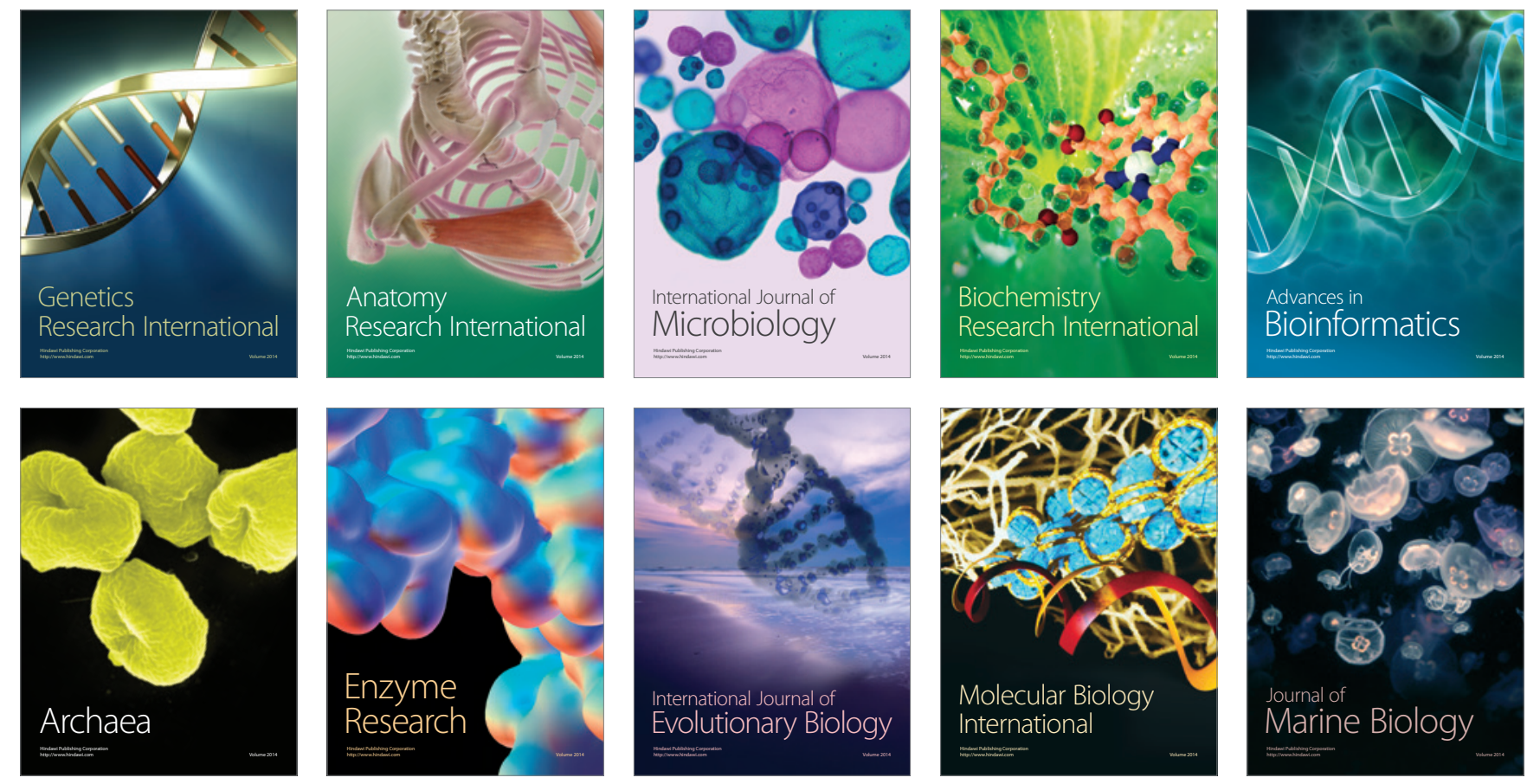